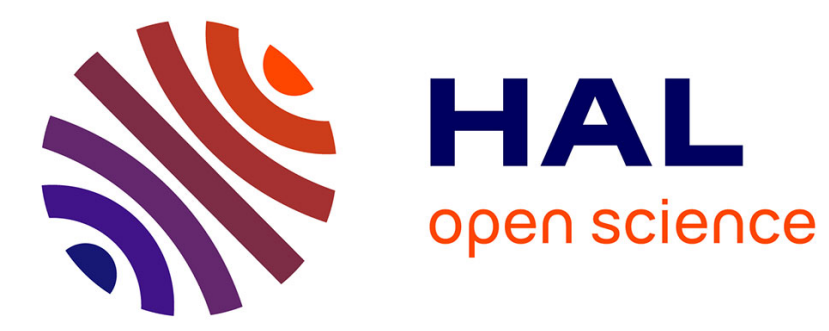

\title{
The strontium isotopic budget of Himalayan rivers in Nepal and Bangladesh
}

\author{
Albert Galy, Christian France-Lanord, Louis Derry
}

\section{To cite this version:}

Albert Galy, Christian France-Lanord, Louis Derry. The strontium isotopic budget of Himalayan rivers in Nepal and Bangladesh. Geochimica et Cosmochimica Acta, 1999, 63 (13-14), pp.1905-1925. 10.1016/s0016-7037(99)00081-2 . hal-03402724

\section{HAL Id: hal-03402724 \\ https://hal.univ-lorraine.fr/hal-03402724}

Submitted on 26 Oct 2021

HAL is a multi-disciplinary open access archive for the deposit and dissemination of scientific research documents, whether they are published or not. The documents may come from teaching and research institutions in France or abroad, or from public or private research centers.
L'archive ouverte pluridisciplinaire $\mathbf{H A L}$, est destinée au dépôt et à la diffusion de documents scientifiques de niveau recherche, publiés ou non, émanant des établissements d'enseignement et de recherche français ou étrangers, des laboratoires publics ou privés. 


\title{
The Strontium Isotopic Budget of Himalayan Rivers in Nepal and Bangladesh
}

\author{
Albert Galy1, Christian France-Lanord ${ }^{1-2} \&$ Louis A. Derry 2 \\ 1: $\quad$ Centre de Recherches Pétrographiques et Géochimiques - CNRS, BP 20, 54501 \\ Vandœuvre-les-Nancy, France \\ email : agaly@crpg.cnrs-nancy.fr \\ 2: Cornell University, Dept.of Geological Sciences. Ithaca, NY 14853-1504, USA \\ Geochimica and Cosmochimica Acta, published in \\ Volume 63, Issues 13-14, July 1999, Pages 1905-1925 \\ https://doi.org/10.1016/S0016-7037(99)00081-2
}

Indexing purpose : Weathering, Ocean, Carbonate, Magnesium, Tibet 


\section{Abstract}

Himalayan rivers have very unusual $\mathrm{Sr}$ characteristics and their budget cannot be achieved by simple mixing between silicate and carbonate even if carbonates are radiogenic. We present $\mathrm{Sr}, \mathrm{O}$, and $\mathrm{C}$ isotopic data from river and rain water, bedload and bedrock samples for the western and central Nepal Himalaya and Bangladesh, including the monsoon season. Central Himalayan rivers receive Sr from several sources: carbonate and clastic Tethyan sediments, High Himalayan Crystalline (HHC) gneisses and granitoids with minor marbles, carbonates and metasediments of the Lesser Himalaya ( $\mathrm{LH})$, and Pliocene-Recent foreland basin sediment from the Siwaliks group and the modern flood plain. In the Tethyan Himalaya rivers have dissolved $[\mathrm{Sr}] \approx 6 \mu \mathrm{mol} / 1$ and ${ }^{87} \mathrm{Sr} /{ }^{86} \mathrm{Sr} \approx 0.717$ with a large contribution from moderately radiogenic carbonate. Rivers draining $\mathrm{HHC}$ gneisses are very dilute with $[\mathrm{Sr}] \approx 0.2$ $\mu \mathrm{mol} / 1$ and ${ }^{87} \mathrm{Sr} /{ }^{86} \mathrm{Sr} \approx 0.74$. Lesser Himalayan streams also have low $[\mathrm{Sr}] \approx 0.4 \mu \mathrm{mol} / \mathrm{l}$ and are highly radiogenic $\left({ }^{87} \mathrm{Sr} /{ }^{86} \mathrm{Sr} \geq 0.78\right)$. Highly radiogenic carbonates of the $\mathrm{LH}$ do not contribute significantly to the Sr budget because they are sparse and have very low [Sr]. In large rivers exiting the Himalaya, Sr systematics can be modeled as a mixture between Tethyan rivers, where slightly radiogenic carbonates (mean ${ }^{87} \mathrm{Sr} /{ }^{86} \mathrm{Sr} \approx 0.715$ ) are the main source of $\mathrm{Sr}$, and Lesser Himalaya waters where extremely radiogenic silicates (>0.8) are the main source of Sr. HHC waters are less important because of their low [Sr]. Rivers draining the Siwaliks foreland basin sediments have $[\mathrm{Sr}] \approx 4 \mu \mathrm{mol} / 1$ and ${ }^{87} \mathrm{Sr} / 86 \mathrm{Sr} \approx 0.725$. Weathering of silicates in the Siwaliks and the flood plain results in a probably significant radiogenic $(0.72$ to 0.74) input to the G-B, but quantification of this flux is limited by uncertainties in the hydrologic budget. The Ganges and Brahmaputra (G-B) in Bangladesh show strong seasonal variability with low [Sr] and high ${ }^{87} \mathrm{Sr} /{ }^{86} \mathrm{Sr}$ during the monsoon. $\mathrm{Sr}$ in the Brahmaputra ranges from $0.9 \mu \mathrm{mol} / 1$ and 0.722 in March to $0.3 \mu \mathrm{mol} / 1$ and 0.741 in August. We estimate the seasonally weighted flux from the G-B to be $6.5 \times 10^{8} \mathrm{~mol} / \mathrm{yr}$ with ${ }^{87} \mathrm{Sr} /{ }^{86} \mathrm{Sr}=0.7295$. 


\section{Introduction}

The Himalaya is an important source of strontium to the world oceans. The Ganges and Brahmaputra rivers are characterized by both high $\mathrm{Sr}$ concentrations and ${ }^{87} \mathrm{Sr} /{ }^{86} \mathrm{Sr}$ ratios (Krishnaswami et al., 1992; Palmer and Edmond, 1989; Palmer and Edmond, 1992). The combination of high Sr concentration and radiogenic isotopic composition gives Himalayan rivers a significant influence on the $\mathrm{Sr}$ isotopic budget of the oceans (Hodell et al., 1990). Despite the importance of the Ganges and Brahmaputra (G-B) flux for the oceanic budget of Sr, at present the isotopic and mass balance of $\mathrm{Sr}$ in this river system is not well understood. It is important to have a quantitative budget for Sr in Himalayan rivers for several reasons. First, the sources of $\mathrm{Sr}$ and its isotopes in the G-B flux must be known in order to test hypotheses that use the Cenozoic marine Sr record as an indicator of global silicate weathering fluxes or Himalayan erosion fluxes (Raymo and Ruddiman, 1992; Richter et al., 1992; Berner and Berner, 1996; Derry and France-Lanord, 1996; Goddéris and François, 1996). Second, the Neogene $\mathrm{Sr}$ isotopic evolution of the G-B river system has recently been defined (Derry and France-Lanord, 1996; Quade et al., 1997), which may be useful for testing models of tectonic and climatic evolution in the Himalayan region. A consistent interpretation of the river isotopic history depends on an improved understanding of the modern budget of $\mathrm{Sr}$ in the G-B system.

Previous studies have identified potential sources for dissolved radiogenic $\mathrm{Sr}$ in Himalayan rivers. Radiogenic Sr is present in both silicate and carbonate rocks exposed in the Himalaya, which has contributed to uncertainty in the mass balance for Sr. Edmond (1992) has highlighted the role of metamorphic redistribution of radiogenic $\mathrm{Sr}$ from $\mathrm{Rb}$-rich minerals such as biotite into easily weatherable minerals such as feldspars as a mechanism for producing stream waters with both high ${ }^{87} \mathrm{Sr} /{ }^{86} \mathrm{Sr}$ and high $\mathrm{Sr}$ concentrations from silicate alteration. Alternatively, Palmer and Edmond (1992) proposed that Himalayan carbonate sediments were enriched in ${ }^{87} \mathrm{Sr}$ during Himalayan metamorphism and weathered to produce stream waters with high ${ }^{87} \mathrm{Sr} /{ }^{86} \mathrm{Sr}$ and $[\mathrm{Sr}]$. Highly radiogenic carbonates are known from the Lesser Himalaya (Derry and France-Lanord, 1996; Singh et al., 1998), and if they were the dominant source of dissolved $\mathrm{Sr}$, the $\mathrm{Sr}$ isotopic mass balance might provide relatively little information about silicate weathering processes. Based on a comparison of ancient detrital and pedogenic carbonates from the Mio-Pliocene Siwalik foreland basin sequence, Quade et al. (1997) have argued that carbonates of the Lesser Himalaya are in fact the primary source of radiogenic $\mathrm{Sr}$ in Himalayan rivers. Two recent studies of riverine $\mathrm{Sr}$ in the high range have argued that carbonate weathering dominates the Sr isotopic signal from the Himalaya (Blum et al., 1998; 
compositions of the Ganges headwaters found that weathering of radiogenic carbonates in the Lesser Himalaya could only account for a modest fraction of the total dissolved $\mathrm{Sr}$, and cannot satisfy the Sr isotopic and mass budget of Ganges (Singh et al., 1998). These workers show the need for an as yet unidentified component with high $\mathrm{Ca} / \mathrm{Sr}$ (Krishnaswami et al., 1992; Singh et al., 1998). Furthermore, while silicate alteration in the high Himalaya must be strongly weathering limited (following the terminology of Stallard and Edmond, 1983) because of very high erosion rates, alteration processes in the low elevation Gangetic floodplain may have an important effect on the isotopic budget of Sr delivered to the ocean (Derry and FranceLanord, 1996). Thus, the basic issue of how the riverine ${ }^{87} \mathrm{Sr} /{ }^{86} \mathrm{Sr}$ ratio in the G-B system reflects weathering processes remains unresolved, despite an increasing number of studies. The uncertainty remains because there is so far no published study which comprehensively examines the Sr systematics of rivers in all the major litho-stratigraphic units that make up the G-B drainage basin. Our ability to interpret existing studies is variously constrained by limited areal extent, and/or lack of bedrock, bedload, atmospheric input or anion data, and in all cases, a lack of data covering the dramatic seasonal variation of the monsoon. Despite the potential importance of Himalayan rivers for weathering and erosion processes and the oceanic $\mathrm{Sr}$ budget, there is only one published ${ }^{87} \mathrm{Sr} /{ }^{86} \mathrm{Sr}$ value for the Ganges and none for the Brahmaputra during the monsoon, when $>90 \%$ of the water discharge takes place.

This paper reports a study of $\mathrm{Sr}$ in Himalayan rivers sampled in the Nepal Himalaya and Bangladesh. We report analyses of rivers draining all the major Himalayan rock units, across an elevation range from 5000 to 20 meters, and from highly arid to rain forest environments. We also report data from the G-B system in Nepal and Bangladesh during the monsoon. We estimate atmospheric inputs of $\mathrm{Sr}$ from analyses of local precipitation. We present an extensive data set from bedrock lithologies and river bedload samples in order to define the $\mathrm{Sr}$ systematics of potential source rocks. These data and the studies cited above demonstrate that the source of dissolved $\mathrm{Sr}$ are complex, and cannot be adequately represented by binary mixing between carbonate and silicate end members. Among Himalayan lithologies, ${ }^{87} \mathrm{Sr} /{ }^{86} \mathrm{Sr}$ ratios vary widely in both silicate and carbonate rocks, as do Sr contents of carbonates. We use the major element chemistry of water (Galy and France-Lanord, in Press) and sediment to characterize the contribution of dissolved $\mathrm{Sr}$ from evaporites, carbonates, and silicates in the different zones of the Himalaya. The combined data sets allow us to construct a consistent isotopic and mass balance for $\mathrm{Sr}$ in the G-B system.

\section{Study area, sampling and hydrochemistry}


Samples were collected in the Narayani and Karnali watersheds which drain two thirds of Nepal Himalaya. The Ganges and Brahmaputra have been sampled in the Bangladesh delta (Fig. $1 \& 2$ ). Himalayan geology can be divided into four units separated by major thrust systems (Le Fort, 1989; Upreti and Le Fort, in press; Fig. 2). The terranes of the northern flank and part of the high Himalaya belong to the Tethyan Sedimentary Series (TSS), composed primarily of Palaeozoic-Mesozoic carbonate and clastic sediments (North Indian shelf sediments). Structurally below the TSS, the High Himalaya Crystalline series (HHC) is the principal formation of the high range. It consists of ortho- and paragneisses, migmatites and highly metamorphosed marbles. Bellow the HHC, the Lesser Himalaya (LH) forms the largest area of the south flank. The LH is composed of variably metamorphosed Precambrian sediments dominated by quartzo-pelitic schists with minor dolomitic carbonates. The Mahabarat nappes in the Lesser Himalaya consist of Palaeozoic marbles and gneisses. The southernmost part of the range is the recently uplifted Siwaliks foreland basin sequence, containing MioPliocene detrital sediments. The Gangetic flood plain has an elevation of ca. $150 \mathrm{~m}$ in Nepal and represents $46 \%$ of the G-B basin area.

Sampling includes (1) main tributaries in the Lesser Himalaya, (2) detailed sampling of the Kali Gandaki river from the northern headwaters in Tibet to the south, (3) minor tributaries draining specific Himalayan formations (TSS, HHC, LH, Siwaliks). In addition the Tista river which drains Sikkim Himalaya has been sampled in Bangladesh. Samples were collected between May 1993 and May 1997 (Tables 1 to 5) mainly during the dry season, except for the Trisuli river which was been sampled repeatedly over one year. The Ganges and Brahmaputra were sampled during the 1996 monsoon and winter of 1997 (Fig 1 and Table 5).

Hydrochemistry of these rivers has been presented elsewhere (Galy and France-Lanord, in Press) and will be briefly summarized below. Table 6 presents the average composition of rivers in the different compartiment of the system. Rivers draining North flank basins have the highest total dissolved solid (TDS) concentration and are characterized by high [ $\left.\mathrm{SO}_{4}\right]$, and locally high $[\mathrm{Cl}]$, such as in the upper Kali Gandaki river. High $\left[\mathrm{SO}_{4}\right]$ appears linked to sulfide oxidation and $\mathrm{Cl}$ input is likely related to thermal springs present in the course of the Upper Kali in the Mustang graben (e.g. LO47, Table 6).

On the south flank of the Himalaya, rivers flowing in carbonate-free basins have low TDS ( $\approx 15$ to $50 \mathrm{mg} / \mathrm{l})$, and Ca comprises some $60 \%$ of the cationic charge. In these rivers the atmospheric contribution may represents up to $50 \%$ of the dissolved load. Basins draining carbonate from the TSS, HHC or LH have higher TDS (100 to $270 \mathrm{mg} / \mathrm{l}$ ) and higher 
The Ganges and Brahmaputra sampled in Bangladesh during the monsoon have chemical characteristics very similar to those of the main Himalayan rivers at the outflow of the range. During the dry season, the Brahmaputra follows an evolution similar to that of Himalayan rivers with a slight increase of TDS (105 to $153 \mathrm{mg} / \mathrm{l})$. In contrast, TDS in the Ganges almost triples (125 to $370 \mathrm{mg} / \mathrm{l}$ ) due to a general increase of ion concentrations, with the notable exception of $\mathrm{K}$ and $\mathrm{SO}_{4}$. The observed trend is consistent with data reported by Sarin et al. (1989) for the Gangetic plain. These authors have shown that during the dry season, the influence of southern tributaries and weathering processes in the flood plain become significant with respect to Himalayan input.

\section{ANALYTICAL PROCEDURE}

Water samples were collected from the river side, filtered through $0.2 \mu \mathrm{m}$ or $0.1 \mu \mathrm{m}$ nylon Millipore filter and stored in bottles free of air. Waters were acidified by adding one drop of strong distilled $\mathrm{HNO}_{3} \cdot{ }^{87} \mathrm{Sr} /{ }^{86} \mathrm{Sr}$ and $\mathrm{Sr}$ concentration by isotope dilution mass spectrometry (IDMS) were measured using a Finnigan Mat 262 in static mode after standard chemical separation techniques, using both Sr-Spec ${ }^{\mathrm{TM}}$ cationic resins (Horwitz et al., 1992) and AG 50-X-8 cationic resins. Some $\mathrm{Sr}$ concentrations were also measured by atomic absorption. $\mathrm{Sr}$ isotopic ratios were normalised to ${ }^{86} \mathrm{Sr} /{ }^{88} \mathrm{Sr}=0.1194$. NBS 987 measurements yielded ${ }^{87} \mathrm{Sr} /{ }^{86} \mathrm{Sr}=0.710197 \pm 17(1 \sigma, \mathrm{n}=117)$ during the period of these analyses. Uncertainties on individual ${ }^{87} \mathrm{Sr} /{ }^{86} \mathrm{Sr}$ measurements were always $<15 \times 10^{-6}(2 \sigma)$. Blank levels on water samples are between 0.07 and $2.7 \mathrm{ng}$, mean of $1.14 \mathrm{ng}$; and ${ }^{87} \mathrm{Sr} /{ }^{86} \mathrm{Sr}$ from 0.712 to 0.724 , mean of 0.716 . Such blank levels will introduce an uncertainty less than 1 part in $10^{4}$ on our analyses.

Rain water samples were filtered in the laboratory. Some samples from Kathmandu have a significant amount of atmospheric dust. A sufficient amount of water was evaporated in order to obtain ca. $60 \mathrm{ng}$ of Sr. Total chemistry blanks were measured routinely along with samples. Sr blanks were 800 - 1200 pg, and the isotopic composition of blanks was 0.709 0.715. [Sr] and $\mathrm{Sr}$ isotopic compositions of rain water have been corrected using the blank measured during the period of analysis. The induced uncertainties are listed in the Table 7. One of the most dilute sample (BGP 2) was duplicated. The first analysis were performed on around $10 \mathrm{ng}$ of $\mathrm{Sr}$, while the second used $35 \mathrm{ng}$. The results were agreed within \pm 0.00006 . In addition, approximately 4 ng of NBS 987 was diluted in sub-boiling distilled water, spiked and similar chemical and blank correction procedures were performed. The value obtained on 
dilute rain waters are determined with at least 3 significant figures. The [Sr] of the KTM samples were measured with an ICP-MS (Perkin Elmer, Elan 6000).

Bedload samples were powdered to a uniform size. The proportions of calcite and dolomite in the bedload were manometricaly determined as $\mathrm{CO}_{2}$ released by selective reaction with $>100 \% \mathrm{H}_{3} \mathrm{PO}_{4}$ (Sheppard and Schwarcz, 1970). Synthetic and natural standards were used to calibrate the time and the temperature of reaction necessary to separate $\mathrm{CO}_{2}$ produced by the dissolution of calcite and dolomite. Greater than $99 \%$ of the calcite had reacted after 3 hours at $25^{\circ} \mathrm{C}$ while dolomite contribute to less than $5 \%$ to the produced $\mathrm{CO}_{2}$. The remaining carbonate was then reacted for $>100$ hours at $50^{\circ} \mathrm{C} . \delta^{18} \mathrm{O}$ (SMOW) and $\delta^{13} \mathrm{C}(\mathrm{PDB})$ were measured on released $\mathrm{CO}_{2}$ using a modified VG-602 mass spectrometer. Overall reproducibility is $\pm 0.1 \%$. For $\mathrm{Sr}$ isotopic analyses, bedload samples were leached with $10 \%$ acetic acid for 30 minutes in an ultrasonic bath. Leachate and residue were separated by centrifuging, and the residue was rinsed repeatedly with distilled water. The first wash was added to the leachate. The bulk powder and the remaining residue were weighed. For sample with more than $10 \mathrm{wt} \%$ carbonate, the weight loss corresponded within $\pm 6 \%$ to the total amount of carbonate without any systematic shift. For the carbonate-poor bedload, the weight loss tended to exceed the measured carbonate content, but there was no correlation between excess weight loss and decreasing carbonate content, indicating that any bias was not systematic. Leachates were evaporated, redissolved in $\mathrm{HNO}_{3}$ and spikes of ${ }^{84} \mathrm{Sr}$ and ${ }^{87} \mathrm{Rb}$ were added. $\mathrm{Rb}$ isotope dilution measurements were made on a Cameca-TSN 206 single collector mass spectrometer. Leachate $\mathrm{Sr}$ separations and isotopic measurement were performed following similar procedures than water. Sr total blanks were 0.48 to $0.72 \mathrm{ng}$ with ${ }^{87} \mathrm{Sr} /{ }^{86} \mathrm{Sr}$ around 0.711 , negligible for the amount of analysed $\mathrm{Sr}$. The $\mathrm{Rb}$ amount $(2.3 \pm 2.0$ ppm) obtained by our leaching process implies very low ${ }^{87} \mathrm{Rb} /{ }^{86} \mathrm{Sr}$ ratios $(0.023 \pm 0.029)$. Acetic acid leaches on clays gave ${ }^{87} \mathrm{Rb} /{ }^{86} \mathrm{Sr}$ ratios between 1.1 and 2.7 (Ohr et al., 1994). Similar treatment of clean carbonates typically releases very little $\mathrm{Rb}\left({ }^{87} \mathrm{Rb} /{ }^{86} \mathrm{Sr}<10^{-2}\right.$, Derry et al., 1992). Low $\mathrm{Rb} / \mathrm{Sr}$ in the leachates and the very low proportion of clay in the bedload samples (around 1\%) are good evidence that $\mathrm{Sr}$ from leachates is derived from carbonates even for carbonate poor samples.

\section{RESULTS}

In this section we present analytical data collected for $\mathrm{Sr}$ concentration and isotopic composition on river waters, rain water and carbonates. We use rain water data to estimate the atmospheric contribution to the dissolved chemistry of the rivers, and data on carbonates from 
bedload and outcrop to determine the characteristics of eroded carbonates in each major lithostratigraphic unit.

\subsection{Dissolved $\mathrm{Sr}$ in rivers}

The isotopic ratio and concentration of dissolved $\mathrm{Sr}$ in all rivers are presented in Figure 3 and listed in Table 1 to 5 . As they enter the floodplain main rivers have ${ }^{87} \mathrm{Sr} /{ }^{86} \mathrm{Sr}$ between 0.725 and 0.768 with [Sr] between 0.3 and $1.8 \mu \mathrm{mol} / \mathrm{l}$. Along the course of the Kali Gandaki ${ }^{87} \mathrm{Sr} /{ }^{86} \mathrm{Sr}$ are low $(\approx 0.715)$ in the north and increase rapidly in the south flank below the MCT (Fig 4). Sr concentrations follow an opposite trend. Similar evolution is observed for other Nepalese rivers such as the Bheri and Trisuli (Tables 2 and 4), the Bhote Kosi (Harris et al., 1998), and the Alaknanda in India (Bickle et al., 1997).

Data for rivers draining a single formation display specific trends (Fig. 3). In the TSS, dissolved $\mathrm{Sr}$ is the least radiogenic of the river system and [Sr] are the highest. This reflects the influence of abundant Palaeozoic carbonate in the basin. Few data are published for other TSS rivers but the upper Bhote Kosi has $[\mathrm{Sr}]$ and ${ }^{87} \mathrm{Sr} /{ }^{86} \mathrm{Sr}$ around $4.8 \mu \mathrm{mol} / \mathrm{l}$ and 0.720 respectively (Harris et al., 1998). The Tsangpo south of Lhasa is also radiogenic with ${ }^{87} \mathrm{Sr} /{ }^{86} \mathrm{Sr}=0.7172$ (Palmer and Edmond, 1989). HHC basins are characterised by low [Sr] and intermediate ${ }^{87} \mathrm{Sr} /{ }^{86} \mathrm{Sr}$ between 0.732 and 0.750 . The $\mathrm{LH}$ rivers have $[\mathrm{Sr}]>0.3 \mu \mathrm{mol} / \mathrm{l}$, and are the most radiogenic, with dissolved ${ }^{87} \mathrm{Sr} /{ }^{86} \mathrm{Sr}$ from 0.758 up to 0.803 . Similar values were found in the LH of western Himalaya (Krishnaswami et al., 1992; Trivedi et al., 1995).

In August, ${ }^{87} \mathrm{Sr} /{ }^{86} \mathrm{Sr}$ and [Sr] are respectively 0.741 and $0.32 \mu \mathrm{mol} / 1$ for Brahmaputra, and 0.729 and $0.56 \mu \mathrm{mol} / 1$ for the Ganges. During the dry season, ${ }^{87} \mathrm{Sr} /{ }^{86} \mathrm{Sr}$ decreases and [Sr] increases. While dry season values are similar to previously published data (Krishnaswami et al., 1992; Palmer and Edmond, 1989; Palmer and Edmond, 1992), our data show that during the monsoon the combined Ganges-Brahmaputra flux is much more radiogenic than previously reported.

\subsection{Dissolved $\mathrm{Sr}$ in rain water}

Rain water has been sampled in Kathmandu during different seasons, and Bangladesh during the 1996 monsoon. ${ }^{87} \mathrm{Sr} /{ }^{86} \mathrm{Sr}$ vary between 0.7096 and 0.7251 and [Sr] vary between 5 and $680 \mathrm{nmol} / \mathrm{l}$ (Table 7) with no apparent relationship. High [Sr] are associated with high 
samples is $166 \mathrm{nmol} / \mathrm{l}$, which is higher than [Sr] in several mountain streams, but this mean is biased by a few very high values. In Bangladesh, the mean value of our sampling is $24 \mathrm{nmol} / \mathrm{l}$. To avoid bias due to a single non representative event, rainfall in Kathmandu was collected continuously during the 1997 monsoon, and sampled every 2 weeks (KTM 1-6). The weighted average of these six samples, covering twelve weeks of deposition, is our best current estimate of mean $[\mathrm{Sr}]$ in rain, $16 \mathrm{nmol} / \mathrm{l}$. Assuming that the average evapotranspiration is $25 \%$ in Nepal (Alford, 1992), we consider that the atmospheric contribution of Sr to river water is $21 \mathrm{nmol} / 1$ with ${ }^{87} \mathrm{Sr} /{ }^{86} \mathrm{Sr} \approx 0.714$.

\subsection{Carbonate rocks}

Himalayan limestone and marbles in the Narayani watershed (Fig. 2a) display a wide range of $[\mathrm{Sr}]$ and ${ }^{87} \mathrm{Sr} /{ }^{86} \mathrm{Sr}$ ratios depending on their geological origin (Table 8, Fig 5). The TSS carbonates have $[\mathrm{Sr}]=250-1600 \mathrm{ppm}$, typical for Phanerozoic carbonates, and slightly variable isotopic ratios $(0.7079$ to 0.7119$)$. $\delta^{18} \mathrm{O}_{\text {smow }}$ are +14 to $+18 \%$ o, lower than marine carbonate and $\delta^{13} \mathrm{C}$ are -2.5 to $0 \%$ (France-Lanord et al., 1988). In Formation II of the HHC, high grade metamorphic marbles have the same characteristics. In contrast, Precambrian dolomites in the $\mathrm{LH}$ have low [Sr] $(28-55 \mathrm{ppm})$ and are very radiogenic with ${ }^{87} \mathrm{Sr} /{ }^{86} \mathrm{Sr}$ up to 0.857. These dolomites outcrop as thin layers in the schist and quartzite of the LH and have low $\delta^{18} \mathrm{O}_{\text {smow }}$ values (15 to $20 \%$ ) due to fluid interaction during Himalayan metamorphism (France-Lanord, 1987) . Their unusual isotopic signatures are due to exchange of Sr during metamorphism with the pelitic country rocks which are extremely radiogenic (0.85 to 1.7 , France-Lanord and Le Fort, 1988). Where Lesser Himalayan carbonate units are thick as in the western Himalaya, the ${ }^{87} \mathrm{Sr} /{ }^{86} \mathrm{Sr}$ ratios are much more like unaltered limestone, with values around 0.709 and [Sr] around 250 ppm (Sarkar et al., 1996; Singh et al., 1998).

\subsection{Bedload carbonate}

Major rivers in the south typically carry 10-14 wt\% of detrital carbonate. Some rivers have significantly different proportions (Marsyandi $\approx 37 \mathrm{wt} \%$; Seti $\approx 46 \mathrm{wt} \%$; Trisuli $\approx 0.60 \%$ ) depending on the lithologies present in their watershed. In Bangladesh the Ganges carries 4 to $7 \mathrm{wt} \%$ carbonate in the bedload whereas the Brahmaputra is almost free of carbonate. Sr-, C-, and $\mathrm{O}$ - isotope compositions of bedload carbonate (Tables 9-10, Fig. 5) have almost the same variability as for Himalayan carbonate rocks. This confirms that these carbonates are detrital material rather than secondary phases such as pedogenic carbonates. In the TSS, bedload 
bedload of HHC catchments (KN $83 \& 101$ ) have higher ${ }^{87} \mathrm{Sr} /{ }^{86} \mathrm{Sr}$ ratios than the Formation II massive carbonate. They may be similar to trace carbonate from Himalayan gneisses in Pakistan (Blum et al., 1998). Samples from LH basins have very radiogenic compositions associated with low [Sr], similar to analyses of LH carbonates. Rivers draining large basins in Nepal, as well as the Ganges and Brahmaputra, have bedload carbonates which define a mixing trend (Fig 5) between Palaeozoic carbonates and a very radiogenic end member such as $\mathrm{LH}$ Himalaya carbonate sample \# AP74-207. ${ }^{87} \mathrm{Sr} /{ }^{86} \mathrm{Sr}$ ratios of carbonate in the three principal trunk rivers in Nepal (Narayani, Karnali, Bheri) are 0.719, 0.723 and 0.728 respectively, and represent the average carbonate transported in the flood plain. Assuming a mixing between Palaeozoic carbonate such as NAG 38 and a LH end member such as AP74-207 (Table 8), the proportion of LH carbonate in these rivers would be 30 to $50 \%$.

\section{SOURCES OF Sr IN HIMALAYAN RIVERS}

\subsection{Budget methodology}

The results obtained from Himalayan rivers show that there are a variety of sources of dissolved $\mathrm{Sr}$ with very different concentrations and isotopic ratios. Unlike in most other rivers, carbonate and silicate sources do not define unique isotopic end members. Rather, the $\mathrm{Ca} / \mathrm{Sr}$ ratio of carbonates varies widely, and both carbonates and silicates display a wide range of ${ }^{87} \mathrm{Sr} /{ }^{86} \mathrm{Sr}$ ratios. In addition, high chloride concentration in some rivers such as the Kali Gandaki headwaters suggest that evaporite dissolution can play a significant role. The combination of these end members in large Himalayan rivers results in a complex blend whose Sr budget is difficult to resolve.

In the first step, we subtract the atmospheric contribution according to mean composition of atmospheric inputs given in section 4.2. Then, the contribution of the different lithologies to the dissolved $\mathrm{Sr}$ of Himalayan rivers will be calculated using $\mathrm{Cl} / \mathrm{Sr}, \mathrm{Na} / \mathrm{Sr}$ and $\mathrm{Ca} / \mathrm{Sr}$ for evaporite, silicate and carbonate sources respectively. We first determine typical values for these ratios based on $\mathrm{Cl}$ rich thermal springs for evaporites, monolitholgic silicate watersheds for silicates, and bedload and outcrop data for carbonates.

\subsection{Evaporite contribution of $\mathrm{Sr}$ in Himalayan rivers}

The Kali Gandaki headwaters, in the Mustang graben, have $\mathrm{Cl}$ content as high as 930 
to $93,000 \mu \mathrm{mol} / \mathrm{l} \mathrm{Cl})$. Evaporite sediments have not been described in the TSS and high $[\mathrm{Cl}]$ in water are not been observed in rivers draining the TSS outside of the graben. In the filling conglomerate of the graben, Fort (1996) describes some discrete evaporite layers, and thermal spring waters are used for salt production. Dissolved $\mathrm{NaCl}$ is therefore likely derived from (1) thermal springs circulating through deeply buried evaporitic formations, and/or (2) groundwater percolating throughout the conglomerates. In the thermal spring $\mathrm{LO} 47, \mathrm{NaCl}$ represent 70 eq\% (Table 6). The other source of dissolved elements is weathering of the conglomerate matrix, derived from the surrounding Mustang leucogranite with no significant carbonate input. $\mathrm{Cl} / \mathrm{Sr}$ and ${ }^{87} \mathrm{Sr} /{ }^{86} \mathrm{Sr}$ of the evaporite end-member can be estimated by mass balance assuming (1) that dissolved load only derives from these two processes, (2) that ${ }^{87} \mathrm{Sr} /{ }^{86} \mathrm{Sr}$ and $\mathrm{Na} / \mathrm{Sr}$ from the leucogranite weathering is $0.750 \pm 0.01$ and $1000 \pm 500$ respectively, as measured from bedload silicate in LO50 or from leucogranite samples (Deniel et al., 1986; Le Fort and FranceLanord, 1995). This results in an evaporite end member with $\mathrm{Cl} / \mathrm{Sr}=650 \pm 60$ and ${ }^{87} \mathrm{Sr} /{ }^{86} \mathrm{Sr}$ $=0.726 \pm 0.003$. Based on this $\mathrm{Cl} / \mathrm{Sr}$ ratio, the evaporite contribution of dissolved $\mathrm{Sr}$ in the Kali mainstream is between 20 and $30 \%$ in the headwaters. However, continental evaporites likely have variable [ $\mathrm{Sr}$ ] and ${ }^{87} \mathrm{Sr} /{ }^{86} \mathrm{Sr}$ as shown by the chemistry of the modern Tibetan endoreic lakes (Chen et al., 1981). Downstream, $\mathrm{Cl}$ is also derived from the metamorphic terranes in the LH, where thermal springs have significantly higher Cl/Sr (1500-2000, Kotarba et al., 1981). Based on $\mathrm{LO} 47$, we use a $\mathrm{Cl} / \mathrm{Sr}$ ratio of 650 which will tend to overestimate the evaporite contribution to the dissolved $\mathrm{Sr}$.

\subsection{Silicate $\mathrm{Sr}$}

Fourteen catchments in HHC and LH which drain only silicate rocks (superscript "s" in the tables) provide a direct measurement of the silicate weathering characteristics in the HHC and LH. HHC and LH rivers have comparable chemistry but markedly different ${ }^{87} \mathrm{Sr} /{ }^{86} \mathrm{Sr}$ which reflects the isotopic contrast between the LH silicates (0.85 to 1.7, Trivedi et al., 1984; France-Lanord and Le Fort, 1988) and the HHC silicates (0.72 to 0.75, Deniel et al., 1986). Weathering of oligoclase feldspar is the principal silicate alteration reaction in Himalayan catchments (Galy and France-Lanord, in Press), therefore we calibrate the silicate $\mathrm{Sr}$ using $\mathrm{Na} / \mathrm{Sr}$ ratios. After correction for the atmospheric contribution which can be as high as $30 \%$, measured $\mathrm{Na} / \mathrm{Sr}$ varies between 300 and 1000 in silicate rich watersheds. $\mathrm{Na} / \mathrm{Sr}$ ratios are negatively correlated with the Ca contribution to the total cationic charge $\left(\mathrm{X}_{\mathrm{Ca}}\right)$ (Fig. 6). The correlation results from dissolution of vein or trace carbonate and occasional intercalated metasedimentary calcic lenses in HHC gneisses (Colchen et al., 1986). Blum et al. (1998) 
eastern syntaxis of the Himalaya. While similar process may contribute to dissolved $\mathrm{Sr}$ in HHC catchments, we note that the $\mathrm{Sr}$ isotopic systematics for the Raikhot gneiss differ considerably from those of the HHC in Nepal, and are much more similar to the LH in Nepal. Carbonate free chemistry is best approached with rivers having low $\mathrm{X}_{\mathrm{Ca}}$ around 0.3 , which corresponds to oligoclase alteration. According to figure 6, waters from end member silicate catchments have a Na/Sr ratio between 700 and 1000. The calculated proportion of dissolved Sr from silicate weathering is between 1-10\% for basins with large areas in TSS and FII carbonates, like the Kali, Marsyandi or Seti, and $15-40 \%$ for predominantly silicate basins such as the Trisuli and Tista rivers.

\subsection{Carbonate $\mathrm{Sr}$}

TSS and HHC carbonates are essentially calcite with $\mathrm{Ca} / \mathrm{Sr}$ molar ratios between 1000 and 2000. Lesser Himalaya carbonates are rich in dolomite (up to 95\%) and have significantly higher $\mathrm{Ca} / \mathrm{Sr}$ (up to 20,000). The low [Sr] of $\mathrm{LH}$ carbonate is also observed in Kumaon and Himachal Himalaya (Singh et al., 1998). Because of the large difference in $\mathrm{Ca} / \mathrm{Sr}$ it is difficult to estimate the proportion of carbonate $\mathrm{Sr}$ in the dissolved load. For major rivers, we can conservatively estimate the fraction of $\mathrm{Sr}$ from carbonate dissolution by making the simplifying assumptions that (1) all dissolved $\mathrm{Ca}$ is from carbonate and (2) all dissolved carbonates have $\mathrm{Ca} / \mathrm{Sr}=1000$. This would imply that for all major Himalayan rivers except the Trisuli, a maximum of $60 \%$ of dissolved $\mathrm{Sr}$ is from carbonate weathering. The actual proportion is necessarily lower because 5 to $10 \%$ of the Ca is released by silicate weathering (Galy and France-Lanord, in Press), and Ca/Sr of LH carbonates are much higher than 1000.

The calcite/dolomite ratio in the bedload is an indication of the composition of eroded carbonates. Because calcite is more soluble than dolomite the bedload chemistry should provide a lower limit for the dissolved $\mathrm{Ca} / \mathrm{Mg}$ ratio.

\section{$5.5 \mathrm{Sr}$ in excess}

Using the characteristics of the different sources of $\mathrm{Sr}$ we can calculate a $\mathrm{Sr}$ budget for the rivers based on measured $[\mathrm{Cl}],[\mathrm{Ca}]$ and $[\mathrm{Na}]$ by the equations : 


$$
\begin{aligned}
& {[\mathrm{Sr}]_{R i v}=[\mathrm{Sr}]_{C y c}+[\mathrm{Sr}]_{E v}+[\mathrm{Sr}]_{S i l}+[\mathrm{Sr}]_{\mathrm{Car}}} \\
& {[\mathrm{Sr}]_{E v}=[\mathrm{Cl}]_{R i v}^{*} \times\left(\frac{[\mathrm{Sr}]}{[\mathrm{Cl}]}\right)_{E v}} \\
& {[\mathrm{Sr}]_{S i l}=\left([\mathrm{Na}]_{R i v}^{*}-[\mathrm{Cl}]_{R i v}^{*}\right) \times\left(\frac{[\mathrm{Sr}]}{[\mathrm{Na}]}\right)_{S i l}} \\
& {[\mathrm{Sr}]_{\mathrm{Car}}=\left([\mathrm{Ca}]_{R i v}^{*}-0.2 \times\left([\mathrm{Na}]_{R i v}^{*}-[\mathrm{Cl}]_{R i v}^{*}\right)\right) \times\left(\frac{[\mathrm{Sr}]}{[\mathrm{Ca}]}\right)_{C a r}}
\end{aligned}
$$

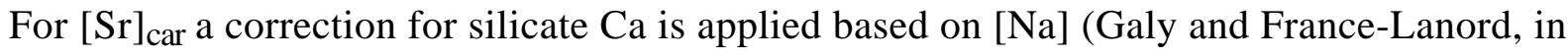
Press). The calculated $[\mathrm{Sr}]_{\mathrm{Riv}}$ is equal to or higher than the measured $[\mathrm{Sr}]_{\mathrm{Riv}}$ only for some rivers. For the Trisuli calculated $[\mathrm{Sr}]_{\mathrm{Riv}}$ corresponds to $95-105 \%$ of the measured $\mathrm{Sr}$. On the south flank, it is around $150 \%$ for HHC basins, $240 \%$ for LH basins and $150 \%$ for the Tista. These over-estimates are unsurprising since (1) our budget assumes that all dissolved $\mathrm{Ca}$ derives from calcite with 800 ppm Sr whereas LH carbonate have much lower [Sr] and (2) the chosen evaporitic $\mathrm{Cl} / \mathrm{Sr}$ ratio is likely too low. The calculated $[\mathrm{Sr}]_{\mathrm{Riv}}$ exceeds the measured value by the greatest amount for rivers draining LH terranes with Sr-poor dolomitic carbonates.

For the large rivers with a large contribution from north flank basins (Kali, Marsyandi, Bheri), only $60 \%$ to $90 \%$ of the actual [Sr] is accounted for by our budget. The excess dissolved Sr over that predicted by the model clearly derives from the northern basins such as the upper Kali or Bheri basins. In these headwaters, only 40-50\% of the dissolved Sr can be explained by our budget. A similar problem is also observed for $\mathrm{Mg}$. A number of rivers such as LO99 or LO103 in the upper basins have $[\mathrm{Mg}]$ close to $[\mathrm{Ca}]$, and much higher than $[\mathrm{Na}]$ and [K]. This results in very high proportions of $\mathrm{Mg}$ (30 to $40 \mathrm{eq} \%$ ) in the Marsyandi headwaters and the main stream of the upper Kali and Bheri. These high proportions of $\mathrm{Mg}$ do not result from silicate weathering because (1) local lithologies are not $\mathrm{Mg}$ rich and (2) $\mathrm{Na}, \mathrm{K}$ and $\mathrm{Si}$ concentrations are at least an order of magnitude lower than $[\mathrm{Mg}]$. Bedload and petrologic data (Bordet et al., 1971; Von Rad et al., 1994) indicate that carbonate units in the basin contain mostly calcite, and carbonate dissolution cannot yield $\mathrm{Mg} / \mathrm{Ca}$ close to 1 (Table 8-10). $\mathrm{Cl}$ concentrations appear independent of the Mg excess, which suggest that evaporite is not the likely source for $\mathrm{Mg}$ as well. The excess $\mathrm{Mg}$ and $\mathrm{Sr}$ is also observed in thermal spring of the Kali headwater (our unpublished data and Kotarba et al., 1981).

A solution to the excess in $\mathrm{Mg}$ and $\mathrm{Sr}$ concentration could be the recrystallization of calcite from surface waters. We have observed extensive carbonate crusts in Mustang around the thermal springs and in the soils. In this arid climate, carbonate precipitates easily because waters are strongly supersaturated with respect to calcite. Mingsen (1981) also described such carbonate precipitation in Tibetan soils. Analyses of these crust show that they contain very 
enrichment in dissolved $\mathrm{Mg}$ and $\mathrm{Sr}$ could result from dissolution of relatively $\mathrm{Mg}$ - and $\mathrm{Sr}$-rich carbonates, and recrystallization of low- $\mathrm{Mg}$ and $-\mathrm{Sr}$ precipitates. $\mathrm{Ca} / \mathrm{Mg}$ fractionation during carbonate weathering is described in laboratory experiments as result of precipitation of secondary calcite with low Mg (Plummer and Mackenzie, 1974). Enrichment of surface waters in $\mathrm{Mg}$ and $\mathrm{Sr}$ via the secondary precipitation of low-Mg and -Sr calcite has been reported from glaciated catchments with carbonate bedrock (Fairchild et al., 1994; Webster et al., 1994). This is likely related to carbonate precipitation during freezing of subglacial streams. Supersaturated ground waters show similar $\mathrm{Mg}$ and $\mathrm{Sr}$ enrichment related to carbonate precipitation (Reeve and Perry, 1994). Sr and Mg "excess" is observed in both glacial water (NAG 24) and thermal springs from Mustang (LO 47 and Kotarba et al., 1981), indicating that these processes occur in Himalayan environments. Water of the upper Kali Gandaki contains significant concentrations of sulfate primarily derived from sulfide oxidation (Galy and France-Lanord, in Press). This could also promote secondary precipitation of gypsum which would have a similar effect of enrichment in dissolved $\mathrm{Mg}$ and Sr. The carbonate precipitation hypothesis supposes that a significant fraction of the low- $\mathrm{Mg}$, low-Sr calcite produced is later re-eroded. Alternatively, $\mathrm{Mg}$ and $\mathrm{Sr}$ could be derived from some unusual evaporitic product. Saline lakes from Tibet are known for their very exotic evaporitic signatures (Zeng Mianping, 1989). This is however not supported by any observation in the Himalaya and we propose that crystallization of secondary carbonate and sulfate is responsible for the observed $\mathrm{Sr}$ and $\mathrm{Mg}$ excess. In this environment carbonate alteration could therefore be described as "incongruent" dissolution. Comparable Mg excesses observed in the Gangetic plain waters during the dry season were also attributed to preferential $\mathrm{CaCO}_{3}$ precipitation in soils (Sarin et al., 1989). One result of the precipitation of low-Sr carbonate is that the $\mathrm{Ca} / \mathrm{Sr}$ ratio will tend to underestimate the $\mathrm{Sr}$ derived from carbonate in the G-B basin.

\subsection{Dissolved Sr Budget in TSS, HHC, LH and Siwaliks}

We can now derive a mass balance for the origin of dissolved $\mathrm{Sr}$ in the different geological zones of the central Nepal river system. These estimates are based on average chemical compositions for river water in the different zones (Fig. 7).

In the TSS, the carbonate contribution is estimated by difference after accounting for evaporite and silicate input using $[\mathrm{Cl}]$ and $[\mathrm{Na}]$. The characteristics of TSS rivers are (1) high $[\mathrm{Sr}]=1$ to $6 \mu \mathrm{mol} / \mathrm{l}$ and (2) the predominance of carbonate $\mathrm{Sr}$ assuming that the $\mathrm{Sr}$ in excess of what can be estimated from the major cation budget is derived from carbonates. Pure TSS 
relatively important. Other major rivers draining large TSS basins such as Bheri khola and Bothe kosi/Trisuli have lower relative $[\mathrm{Cl}]$, and hence lower contributions of evaporitic $\mathrm{Sr}$.

For HHC streams, [Sr] is typically low between 0.1 and $0.3 \mu \mathrm{mol} / \mathrm{l}$. Most sampled rivers are from catchments in paragneisses of the $\mathrm{HHC}$ which are almost pure silicate. There, trace carbonates (and possibly carbonate dust) deliver between 0 and $50 \%$ of the dissolved $\mathrm{Sr}$, but the total flux of $\mathrm{Sr}$ is low. Samples of the Langtang khola provide an example of contribution of the whole HHC, including marbles. The upper limit for carbonate $\mathrm{Sr}$ can be estimated from $\mathrm{X}_{\mathrm{Ca}}$ values (Fig. 6) assuming that (1) carbonates deliver a $\mathrm{Ca} / \mathrm{Sr}$ ratio of 1500 (Table 8-10), and (2) a Na/Sr of 800 for the silicate input. In this river ca. $40 \%$ of the $\mathrm{Sr}$ is derived from silicate and $60 \%$ from carbonate.

Rivers in the LH have low [Sr] around $0.4 \mu \mathrm{mol} / \mathrm{l}$, close to the average contribution of LH rivers in western Himalaya (Krishnaswami et al., 1992; Trivedi et al., 1995). The evaporite contribution does not exceed $10 \%$, when applying a $\mathrm{Cl} / \mathrm{Sr}$ of 1500 , defined by local spring water in the Kali Gandaki (Kotarba et al., 1981). The average contribution of carbonate Sr to the dissolved load is around $40 \%$. The very low [ $\mathrm{Sr}]$ of the LH carbonates is the main reason for their minor influence on the dissolved Sr budget of the larger rivers. For instance, despite a $[\mathrm{Ca}]+[\mathrm{Mg}]$ as high as $1600 \mu \mathrm{mol} / \mathrm{l}$ from dolomite dissolution, the dissolved $[\mathrm{Sr}]$ can be as low as $0.2 \mu \mathrm{mol} / \mathrm{l}$ in samples $\mathrm{NH} 7$ and 94-12.

Most rivers in the Siwaliks have high [Sr], around $4 \mu \mathrm{mol} / \mathrm{l}$ related to very high TDS around $600 \mathrm{mg} / \mathrm{l}$. Na is the dominant cation in these rivers implying that plagioclase alteration is the source for ca. 80\% of the dissolved Sr. These Siwalik rivers (e.g. 94-02 and 94-18, Table 4) are very different from other south flank rivers given that their [Sr] is an order of magnitude higher and is dominantly of silicate origin. In some other Siwalik catchments (e.g. 94-13 and 94-14, Table 4), carbonate dissolution is the major source of dissolved elements, with Ca comprising more than 90 eq\% of the cations. In this case [ $\mathrm{Sr}]$ is significantly lower but isotopic ratios remain relatively high. This is consistent with the fact that both detrital and pedogenic carbonate have radiogenic compositions around 0.720-0.740 in the Siwaliks (Quade et al., 1997).

\section{CONTROL OVER THE Sr ISOTOPIC COMPOSITION OF HIMALAYAN RIVERS}


North of the Siwaliks, the relative importance of the different source of $\mathrm{Sr}$ in main Himalayan rivers can be estimated using combined ${ }^{87} \mathrm{Sr} /{ }^{86} \mathrm{Sr}$ and $[\mathrm{Sr}]$ of rivers for the different zones (TSS, HHC, LH) given in Table 11 and presented in Figure 8a. Samples of the Kali Gandaki lie on the mixing trend between TSS and LH waters. This implies that the contribution of the low $[\mathrm{Sr}]$ water derived from HHC terrains does not represent a significant source of $\mathrm{Sr}$ in the Kali Gandaki. The Trisuli basin is more clearly influenced by HHC type of waters. There are significant differences between the tributaries of the Narayani which are consistent with the bedrock geology in each basin. The Sr budget can be used to calculate the flux of water derived from basins on each unit which can be compared to hydrological data. The results of this Sr hydrological budget are presented in Table 11 together with hydrological modelling of the river system (Hurtrez, 1998). This modelling is based on the integration of Nepal meteorological data for precipitation and the area of each geological unit in the basins. Both approaches compare well, which supports our overall approach (Table 11). The Narayani has a relatively homogeneous composition.

From this budget it is clear that $\mathrm{Sr}$ in the Narayani river is controlled essentially by the contributions from the LH and TSS. HHC waters are a minor contributor to the Narayani budget, because they have low [Sr]. About $65 \%$ of the Narayani Sr is derived from TSS. Combining the lithological budget of dissolved $\mathrm{Sr}$ in the different units (Fig. 7) and the contributions from each formation to the dissolved Sr load (Fig. 8) we can estimate the sources of Sr for the Narayani, Kali and Trisuli (Fig. 9). The main features are that (1) 65 to $75 \%$ of Sr is derived from carbonate dissolution, (2) TSS carbonates account for more than $50 \%$ of $\mathrm{Sr}$, (3) evaporite $\mathrm{Sr}$ is variable but can reach $15 \%$ in the Kali, and (4) silicate $\mathrm{Sr}$ is mostly derived from LH and represent 15 to $20 \%$ of the dissolved load.

\subsection{Other Himalayan rivers}

$\mathrm{Sr}$ isotopic data for main rivers in the Himalaya from this and previous studies are presented in Figure 8b (Krishnaswami et al., 1992; Palmer and Edmond, 1992; Trivedi et al., 1995). With the notable exception of the Tista, other studied rivers have Sr characteristic comparable to those of the Narayani watershed. Assuming that comparable sources are involved in their watersheds they all suggest that evaporite and carbonates in the TSS are the largest source of dissolved $\mathrm{Sr}$ in Himalayan rivers. From their study of the Ganges headwaters in the western Himalaya, Singh et al. (1998) inferred the need for a source of 
the western Himalaya as well. The Bothe Kosi sampled in the LH is an exception since TSS contribution is certainly very low in this river, and most of the is Sr derived from alteration of the LH (Harris et al., 1998). Harris et al. (1998) propose that $60 \%$ of the $\mathrm{Sr}$ comes from LH carbonate, but because they assume "normal" [Sr] for LH carbonates they substantially overestimate the impact of carbonate dissolution. For the Tista (sampled in Bangladesh) the budget is also clearly different. This river does not have any TSS in its watershed which explains its very radiogenic ${ }^{87} \mathrm{Sr} / 86 \mathrm{Sr}$ and low $\mathrm{Sr}$ concentration.

\subsection{Flood plain}

In the flood plain other sources contribute to the Ganges and Brahmaputra rivers (Fig. 8c). This includes (1) addition of rivers draining the Siwaliks which have ${ }^{87} \mathrm{Sr} / 86 \mathrm{Sr}$ near 0.725 with high [Sr], (2) in situ weathering reactions in the flood plain as illustrated by data from ground waters or the Gomti river (Palmer and Edmond, 1992), and (3) for the Ganges the tributaries draining the Indian shield and the Deccan traps (Krishnaswami et al., 1992). Ground waters of the the flood plain, as well as the Gomti river which drains only the flood plain, have chemical characteristics very similar to those of the Siwaliks rivers. Their cation chemistry (Sarin et al., 1989) is dominated by Na which implies that, unlike Himlalayan rivers, the main source of dissolved $\mathrm{Sr}$ is silicate alteration.

In the Ganges, the influence of less radiogenic southern tributaries is observed only during the dry season (Krishnaswami et al., 1992). Downstream, the combined influence of major Himalayan and Siwalik tributaries and of flood plain waters raise the Ganges $\mathrm{Sr}$ isotopic ratio. During the monsoon ${ }^{87} \mathrm{Sr} /{ }^{86} \mathrm{Sr}$ in the Ganges increases under enhanced influence of the Himalayan and possibly flood plain input. While this scenario provides a consistent explanation of the Ganges Sr characteristics, with the available set of data it is very difficult to quantify the relative importance of the different sources of Sr. Because the Siwalik-flood plain "end member" lies near the mixing line between LH and TSS sources (Fig 8c) the Sr data cannot resolve the importacne of these sources. The Siwalik-flood plain could be a significant source of Sr derived from silicate weathering, but without improved hydrologic data it is difficult to constrain their importance. In addition, the hydrological budget of the Ganges and $\mathrm{Ba}$ and Ra data in the Bay of Bengal imply that there is a significant hidden flux of groundwater to the ocean (Moore, 1997; Galy and France-Lanord, in Press). Given these uncertainties the budget of $\mathrm{Sr}$ in the Ganges basin remain poorly quantified both in terms of flux and origin.

The Brahmaputra river differs from the Ganges, and has chemical characteristics similar 
low [Sr]. A simple explanation is that flood plain processes are less important than for the Ganges because the area of the Brahmaputra floodplain is reduced by the Shillong plateau uplift, and the Brahmaputra lacks important southern tributaries. As with the Himalayan rivers, the TSS represent an important source of Sr. The Brahmaputra shows marked seasonal variation. During the monsoon, the Brahmaputra has lower $[\mathrm{Sr}]$ but is very radiogenic ${ }^{87} \mathrm{Sr} /{ }^{86} \mathrm{Sr} \approx 0.740$ ), very similar to monsoon waters from the Trisuli (Fig. 8). Tributaries and headwaters in the Brahmaputra basin have been little studied, but the monsoon signal is consistent with the Himalayan geology of the basin which is strongly dominated by HHC terranes (Gansser, 1983).

\section{GANGES-BRAHMAPUTRA EFFECT ON SEAWATER ISOTOPIC COMPOSITION}

Our data from the Ganges and Brahmaputra (Table 5) show considerable seasonal variability. The data obtained in August imply that the annual G-B flux of Sr to the ocean is lower but notably more radiogenic than previous estimates (Krishnaswami et al., 1992; Palmer and Edmond, 1992). In order to calculate the G-B flux of $\mathrm{Sr}$ we can extrapolate the measured data close to the mouth (Palmer and Edmond, 1989) and seasonal variability to calculate a flux of Sr based on average monthly discharge (Hossain et al., 1987). This results in a G-B flux of $8.22 \times 10^{8} \mathrm{~mol} / \mathrm{yr}$ with a ${ }^{87} \mathrm{Sr} / 86 \mathrm{Sr}$ of 0.7295 . However the same calculation applied to $\mathrm{Ca}$ is significantly higher than the average yearly fluxes published by the GEMS/Water program (UNESCO). Another approach is to use the clear relationship between $\mathrm{Ca}$ and $\mathrm{Sr}$ for Ganges and Brahmaputra (Fig. 10) and calculate the $\mathrm{Sr}$ concentration assuming $\mathrm{Ca}$ reported by GEMS/Water program. The exercise seems correct for the Ganges, with mean annual concentrations between monsoonal and winter data. The resulting Ganges flux is $3.52 \times 10^{8}$ $\mathrm{mol} / \mathrm{yr}$. In contrast, for the Brahmaputra the annual GEMS Ca is significantly lower than our measured concentrations during the monsoon. This result in yearly flux of $\mathrm{Sr}$ for Brahmaputra of only $1.36 \times 10^{8} \mathrm{~mol} / \mathrm{yr}$ which is likely too low. It is moreover very difficult to extrapolate this result to isotopic ratios since for the Brahmaputra there is a marked increase of ${ }^{87} \mathrm{Sr} / 86 \mathrm{Sr}$ with decreasing Sr. It is possible that the reported GEMS value for Brahmaputra is not representative. Because of this problem we prefer to use the extrapolation based on our own data which gives a Sr flux of $2.96 \times 10^{8} \mathrm{~mol} / \mathrm{yr}$ with ${ }^{87} \mathrm{Sr} /{ }^{86} \mathrm{Sr}=0.7339$ for Brahmaputra. The resulting G-B flux is $6.5 \times 10^{8} \mathrm{~mol} / \mathrm{yr}$ which is only $50 \%$ of the flux proposed by Richter et al. (1992) and corresponds to $1.9 \%$ of the world river delivery to the ocean according to the global budget of Palmer and Edmond (1989). 
The variation of the marine ${ }^{87} \mathrm{Sr} / 86 \mathrm{Sr}\left(\mathrm{R}_{\mathrm{SW}}\right)$ can be described by :

$$
\frac{d R_{S W}}{d t}=\frac{1}{\tau_{S r}}\left(\frac{J_{G B}}{J_{t o t}}\left[R_{G B}-R_{S W}\right]+\frac{J_{R}}{J_{t o t}}\left[R_{R}-R_{S W}\right]+\frac{J_{H}}{J_{t o t}}\left[R_{H}-R_{S W}\right]+\frac{J_{D}}{J_{t o t}}\left[R_{D}-R_{S W}\right]\right)
$$

where the $J$ and $R$ are the Sr fluxes and ratios to sea water (SW) from the G-B, all other rivers (R), hydrothermal (H) and diagenesis (D) respectively (Brass, 1976; Goldstein and Jacobsen, 1987). $\tau_{\mathrm{Sr}}$ is the oceanic residence time of Sr. The mass balance for the $\mathrm{Sr}$ isotopic composition of sea water can be calculated from the estimated input values for the GB, the flux from all other rivers (R), diagenesis (D), and hydrothermal sources $(H)$. Values for several of the inputs to the oceans have been estimated independently: (1) a $\mathrm{Sr}$ diagenetic input of $3.4 \times 10^{9} \mathrm{~mol} / \mathrm{yr}$ with a ${ }^{87} \mathrm{Sr} / 86 \mathrm{Sr}=0.7084$ (Palmer and Edmond, 1989); and (2) a riverine $\mathrm{Sr}$ flux excluding the G-B of $32.03 \times 10^{9} \mathrm{~mol} / \mathrm{yr}$ with a ${ }^{87} \mathrm{Sr} /{ }^{86} \mathrm{Sr}=0.7114$ (after Palmer and Edmond, 1989); (3) we use our data to estimate the GB flux of $6.5 \times 10^{8} \mathrm{~mol} / \mathrm{yr}$ with ${ }^{87} \mathrm{Sr} / 86 \mathrm{Sr}$ $=0.7295$. The remaining term, $\mathrm{J}_{\mathrm{H}}$, is poorly known independently but can be calculated if the derivative of the $\mathrm{Sr}$ isotopic curve is known, using the value of $\mathrm{R}_{\mathrm{H}}=0.7035$ (Palmer and Edmond, 1989). The mean rate of change of ${ }^{87} \mathrm{Sr} /{ }^{86} \mathrm{Sr}_{\mathrm{SW}}$ over the last $2.5 \mathrm{Ma}$ has been $54 \times 10^{-6} \mathrm{Ma}^{-1}$ (Hodell et al., 1990), which yields a value of $\mathrm{J}_{\mathrm{H}}=13.2 \times 10^{9} \mathrm{~mol} \mathrm{Sr} / \mathrm{yr}$. In the absence of any flux from the $\mathrm{GB}, \mathrm{dR}_{\mathrm{SW}} / \mathrm{dt}$ would be $-48 \times 10^{-6} \mathrm{Ma}^{-1}$, demonstrating that the GB flux exerts a major control on the rate of change of the marine Sr ratio. The very high ${ }^{87} \mathrm{Sr} /{ }^{86} \mathrm{Sr}$ value of modern sea water is supported by the very radiogenic GB flux.

A hydrothermal flux of ca. $13 \times 10^{9} \mathrm{~mol} \mathrm{Sr} / \mathrm{yr}$ implies mid-ocean ridge heat and water fluxes that are a factor of 4-5 higher than those obtained by geophysical and other geochemical methods (Elderfield and Schultz, 1996). The discrepancy can be partially ameliorated by considering a marine $\mathrm{Sr}$ balance even further from steady state than suggested by the mean Pleistocene value for $\mathrm{dR}_{\mathrm{SW}} / \mathrm{dt}$. To test whether a non-steady state model can successfully reconcile the $\mathrm{Sr}$ mass balance with other estimates of the hydrothermal flux we take the mean Pleistocene value of $\mathrm{dR}_{\mathrm{SW}} / \mathrm{dt}$ to result from an "interglacial" flux equivalent to the modern values, and a "glacial" flux with a $25 \%$ reduction in the Sr flux from all rivers. We do not change ${ }^{87} \mathrm{Sr} /{ }^{86} \mathrm{Sr}$ for any flux, although decreased shield weathering could lower the mean isotopic ratio of runoff during glacial conditions (Blum and Erel, 1995). Increased dissolution of reef carbonate during low sea level stand slows the rate of change of RSW (Stoll and Schrag, 1998) . We choose the duration of the glacial interval to be $2 / 3$ of a climatic cycle, while the interglacial is $1 / 3$. The overall slope necessarily matches the Pleistocene average, but the interglacial (present day) value of $\mathrm{dR}_{\mathrm{SW}} / \mathrm{dt}$ is $3 \times$ higher $\left(172 \times 10^{-6} \mathrm{Ma}^{-1}\right)$, and the glacial $\mathrm{dR} / \mathrm{dt}$

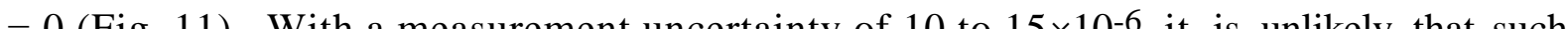


changes in $\mathrm{dR}_{\mathrm{SW}} / \mathrm{dt}$ can be detected over the time scale of Pleistocene climate cycles (e.g. Clemens et al., 1994). This arbitrary "step" history for $\mathrm{R}_{\mathrm{SW}}$ permits a reduction in the hydrothermal flux to $10.7 \times 10^{9} \mathrm{~mol} \mathrm{Sr} / \mathrm{yr}$. The calculation demonstrates the sensitivity of the hydrothermal flux estimate to assumptions about the current state of the marine $\mathrm{Sr}$ balance. However, even this reduced value of $\mathrm{J}_{\mathrm{H}}$ does not bring the Sr-based estimate into agreement with the axial hydrothermal flux estimate of (Stoll and Schrag, 1998), who suggest an axial flux of about $2.9 \times 10^{9} \mathrm{~mol} \mathrm{Sr} / \mathrm{yr}$. If this axial flux were the only source of unradiogenic $\mathrm{Sr}$ to the oceans the modern river data would imply a present day $\mathrm{dR}_{\mathrm{SW}} / \mathrm{dt} \approx 526 \times 10^{-6} \mathrm{Ma}^{-1}$, an order of magnitude higher than the observed mean rate. It is highly unlikely that any reasonable glacial-interglacial changes in river fluxes and ratios could satisfy the Pleistocene mean with such a low hydrothermal flux. In any case, such extreme rates of change should produce variations in ${ }^{87} \mathrm{Sr} /{ }^{86} \mathrm{Sr}_{\mathrm{SW}}$ during a climate cycle that are detectable with high resolution sampling, but these have not been reported. The Sr mass balance in the oceans apparently requires a large source of non-radiogenic $\mathrm{Sr}$ other than the axial ridge flux. For an axial flux value of $2.9 \times 10^{9} \mathrm{~mol} \mathrm{Sr} / \mathrm{yr}$, and ${ }^{87} \mathrm{Sr} /{ }^{86} \mathrm{Sr}$ of 0.7035 for both axial and non-axial fluxes, an approximate minimum estimate for the magnitude of the non-axial flux of unradiogenic $\mathrm{Sr}$ is $3.1 \pm 0.5$ times greater than the axial flux, if either the glacial-interglacial step or linear history for $\mathrm{dR}_{\mathrm{SW}} / \mathrm{dt}$ are realistic. This large non-axial unradiogenic flux must comprise low temperature alteration of the oceanic crust, and possibly weathering of $\mathrm{Sr}$ from maficintermediate terranes such as Oceania, which may be currently underestimated in the global river budget (Louvat, 1997). While models often scale the "hydrothermal" flux of Sr to past rates of oceanic crust production, if most of the unradiogenic $\mathrm{Sr}$ flux to the oceans is non-axial, such scaling may not be a robust way to predict past variations in the Sr flux to the oceans.

\section{SUMMARY AND CONCLUSION}

For rivers draining the central Himalaya, we find that about $60 \%$ of the dissolved $\mathrm{Sr}$ is is derived from sediments of the TSS. TSS rivers, as documented in the Kali Gandaki watershed, have high [Sr] around $5 \mu \mathrm{mol} / 1$ and low ${ }^{87} \mathrm{Sr} /{ }^{86} \mathrm{Sr}$, near 0.717 . Still, the $[\mathrm{Sr}]$ is high for the given ${ }^{87} \mathrm{Sr} /{ }^{86} \mathrm{Sr}$ compared to "normal" rivers (e.g. Edmond and Huh, 1997) and this is related (1) to the presence of radiogenic evaporites, (2) to the moderatly radiogenic character of carbonate with ${ }^{87} \mathrm{Sr} /{ }^{86} \mathrm{Sr} \approx 0.711$ and (3) to processes involving carbonate dissolution and recrystallization. These latter processes are likely specific to the arid and glaciated environments of the north basins. Previous studies by Krishnaswami et al. (1992) of western Himalayan rivers have highlighted the role of weathering of the highly radiogenic 
rivers in central Nepal confirms this interpretation. As in western Himalaya (Singh et al., 1998), the role of the highly radiogenic carbonates of the LH appears accessory in the general budget of the rivers. Weathering in the crystalline rocks of the HHC represents a minor source of dissolved Sr except in the Trisuli river. This contrasts strongly with the budget of physical erosion, where the HHC is the source for ca. $80 \%$ of the eroded material (France-Lanord et al., 1993; Galy et al., 1996). Himalayan rivers are strongly "weathering limited", and rapid physical erosion is a limiting factor for the increase of the riverine ${ }^{87} \mathrm{Sr} /{ }^{86} \mathrm{Sr}$, and for chemical weathering in general (Galy and France-Lanord, in Press).

To first order, our data (and other published data on Himalayan rivers) can be modelled with the assumption that Himalayan river $\mathrm{Sr}$ is derived from a mixture of carbonate sources of $\mathrm{Sr}$ from the TSS and highly radiogenic Sr derived from silicates of the LH. Although dissolution of $\mathrm{Sr}$ from metamorphosed carbonates contributes to Himalayan rivers, our data do not support proposals that highly radiogenic carbonates are the main source of radiogenic $\mathrm{Sr}$ (Quade et al., 1997; Blum et al., 1998; Harris et al., 1998). The low Sr content of the very radiogenic carbonates minimizes their impact on the river budget (e.g. Singh et al., 1998).

Rivers in the Siwaliks have isotopic compositions similar to those of Himalayan rivers, but with higher [ $\mathrm{Sr}]$. Unlike Himalayan rivers, most of their $\mathrm{Sr}$ is derived from weathering of silicates which are mostly HHC-derived detrital sediments. Ground waters in the flood plain have the same characteristics and are also systems where HHC silicate is a significant source for Sr. The importance of Siwalik rivers and of reactions in flood plain soils and ground waters on the final composition of the G-B remains uncertain, because of large uncertainties in the flood plain hydrological budget.

During the monsoon, available data show that the Ganges and Brahmaputra rivers become more radiogenic and more dilute with respect to $\mathrm{Sr}$. The change is consistent with an increased source of Sr from HHC material, although whether the alteration takes place in the high range or flood plain is not yet clear.

The unusual Sr signature of Himalayan rivers is in large part caused by the metamorphic redistribution of ${ }^{87} \mathrm{Sr}$ from $\mathrm{Rb}$-rich minerals such as micas into more easily weatherable minerals such as plagioclase (Edmond, 1992). Carbonate weathering primarily acts to dilute this effect, increasing $[\mathrm{Sr}]$ and decreasing the isotopic ratio. Long term variability of the G-B can therefore be achived reducing the TSS input relative to either LH and HHC in Himalaya and/or floodplain contributions. High values for ${ }^{87} \mathrm{Sr} /{ }^{86} \mathrm{Sr}$ but low flux from the G-B during some of the last $10 \mathrm{Ma}$ (Derry and France-Lanord, 1996; Quade et al., 1997) likely also result from decreased carbonate contribution and increased silicate weathering. Better constraints on flood plain processes are necessary to construct a complete Sr budget for the modern Ganges- 
Acknowledgments - We thank Ananta Gajurel for his constant help in sampling river and rain waters in Nepal during the monsoons 93 and 97. In addition we thank all our colleagues who helped us for sampling in different parts of Nepal and Bangladesh. Technical assistance and laboratory facilities were provided by Jean Carignan, Pierre Coget, Laurie Reisberg and Catherine Spatz. We thank Prof S. Krishnaswami and an anonymous reviewer for constructive suggestions improving this manuscript. This study was supported by the CNRS Programs DBT "Fleuve et Érosion" and PROSE. AG was supported by a Grant of CNRS and Région Lorraine during this study. This is contribution CRPG \#1400 and INSU DBT \#163. 


\section{References}

Alford D. (1992) Hydrological aspects of the Himalayan region. ICIMOD Occasional paper.

Berner R. A. and Berner E. (1996) Global Environment : Water, Air, and Geochemical Cycles. Prentice Hall.

Bickle M., Chapman H., Bunbury J., Harris N., and Fairchild I. (1997) Orogenic control of seawater Sr isotopic compositions: constrains from Himalayan rivers. EUG 9, 251.

Blum J. D. and Erel Y. (1995) A silicate weathering mechanism linking increases in marine ${ }^{87} \mathrm{Sr} /{ }^{86} \mathrm{Sr}$ with global glaciation. Nature $373,415-418$.

Blum J. D., Gazis C. A., Jacobson A. D., and Chamberlain C. P. (1998) Carbonate versus silicate weathering in the Raikhot watershed within the High Himalayan Crystalline Series. Geology 26, 411-414.

Bordet P., Colchen M., Krummenacher D., Le Fort P., Mouterde R., and Remy M. (1971) Recherches Géologiques dans l'Himalaya du Népal, Région de le Thakkhola. Centre National de la Recherche Scientifique.

Brass G. W. (1976) The variation of the marine $87 \mathrm{Sr} / 86 \mathrm{Sr}$ ratio during Phanerozoic time: interpretation using a flux model. Geochim. Cosmochim. Acta 40, 721-730.

Brouand M. (1989) Pétrogenese des migmatites de la dalle du Tibet (Himalaya du Népal). , Institut National Polytechnique de Lorraine, Nancy.

Chen K.-Z., Yiang S.-X., and Zhen X.-Y. (1981) The saline lakes on the Qinghai-Xizang plateau. In Geological and Ecological Studies of Qinghai-Xizang plateau, Vol. 2, pp. 17191724. Science Press.

Clemens S. C., Gromet L. P., and Farrell J. W. (1994) The 100,000 year cyclicity in seawater ${ }^{87} \mathrm{Sr} /{ }^{86} \mathrm{Sr}$ : an enviro-analytical artifact? Mineral. Mag. 58A, 179-180.

Colchen M., Le Fort P., and Pêcher A. (1986) Notice explicative de la carte géologique Annapurna-Manaslu-Ganesh (Himalaya du Népal) au 1:200.000e (bilingue: françaisenglish). Centre National de la Recherche Scientifique.

Deniel C. (1985) Apport des isotopes du Sr, du Nd et du Pb à la connaissance de l'âge et de l'origine des leucogranites himalayens. Exemple du Manaslu (Himalaya, Népal). Université de Clermont-Ferrand.

Deniel C., Vidal P., and Le Fort P. (1986) Les leucogranites himalayens et leur région source probable : les gneiss de la "Dalle du Tibet". C. R. Acad.Sci. (Paris) 303, II, 57-60.

Derry L. A. and France-Lanord C. (1996) Neogene Himalayan weathering history and river ${ }^{87} \mathrm{Sr} /{ }^{86} \mathrm{Sr}$ : Impact on the marine Sr record. Earth Planet. Sci. Lett. 142, 59-74. 
Derry L. A., Kaufman A. J., and Jacobsen S. B. (1992) Sedimentary Cycling and environmental change in the Late Proterozic: evidence from stable and radiogenic isotopes. Geochim. Cosmochim. Acta 56, 1317-1329.

Edmond J. M. (1992) Himalayan tectonics, weathering processes, and the strontium isotope record in marine limestones. Science 258, 1594-1597.

Edmond J. M. and Huh Y. (1997) Chemical weathering yields from basement and orogenic terrains in hot and cold climates. In Tectonic Uplift and Climate Change (ed. W. F. Ruddiman), pp. 329-351. Plenum Press.

Elderfield H. and Schultz A. (1996) Mid-ocean ridge hydrothermal fluxes and the chemical composition of the ocean. Annu. Rev. Earth Planet. Sci. 24, 191-224.

Fairchild I. J., Bradby L., Sharp M., and Tison J.-L. (1994) Hydrochemistry of carbonate terrains in alpine glacial settings. Earth Surface Processes and Landforms 19, 33-54.

Fort M. (1996) Late Cenozoic environmental changes and uplift on the northern side of the central Himalaya: a reappraisal from field data. Paleo. Paleo Paleo. 120, 123-145.

France-Lanord C. (1987) Chevauchement, métamorphisme et magmatisme en Himalaya du Népal central. Etude isotopique H, C, O. Thèse de l'Institut National Polytechnique de Lorraine, Nancy.

France-Lanord C., Derry L., and Michard A. (1993) Evolution of the Himalaya since Miocene time: isotopic and sedimentologic evidence from the Bengal Fan. In Himalayan Tectonics, Vol. 74 (ed. P. J. Treloar and M. Searle), pp. 603-621. Geol. Soc. Lond.

France-Lanord C. and Derry L. A. (1997) Organic carbon burial forcing of the carbon cycle from Himalayan erosion. Nature 390, 65-67.

France-Lanord C. and Le Fort P. (1988) Crustal melting and granite genesis during the Himalayan collision orogenesis. Transactions of the Royal Society of Edinburgh Earth Sciences 79, 183-195.

France-Lanord C., Sheppard S. M. F., and Le Fort P. (1988) Hydrogen and oxygen isotope variations in the High Himalaya peraluminous Manaslu leucogranite : evidence for heterogeneous sedimentary sources. Geochim. Cosmochim. Acta 52, 513-526.

Galy A. and France-Lanord C. (in Press) Processes of the Weathering in the GangesBrahmaputra basin and the riverine alkalinity budget. Chem. Geol.

Galy A., France-Lanord C., Hurtrez J. E., and Lucazeau F. (1996) Mass Transfer During Himalayan Erosion During the Monsoon : Mineralogical and Geochemical constraints. $A G U$ Fall meeting, F236.

Gansser A. (1983) Geology of the Bhutan Himalaya. Birkhaüser Verlag.

Goddéris Y. and François L. M. (1996) Balancing the Cenozoic carbon and alkalinity cycles: 
Goldstein S. J. and Jacobsen S. B. (1987) The Nd and Sr isotopic systematics of river-water dissolved material: implications for the sources of $\mathrm{Nd}$ and $\mathrm{Sr}$ in seawater. Chem. Geol. 66 , 245-272.

Harris N., Bickle M., Chapman H., Fairchild I., and Bunbury J. (1998) The significance of Himalayan rivers for silicate weathering rates: evidence from the Bhote Kosi tributary. Chem. Geol. 144, 205-220.

Hodell D. A., Mead G. A., and Mueller P. A. (1990) Variation in the strontium isotopic composition of seawater ( $8 \mathrm{Ma}$ to present): Implications for chemical weathering rates and dissolved fluxes to the oceans. Chem. Geol. 80, 291-307.

Horwitz E. P., Chiarizia R., and Dietz M. L. (1992) A novel strontium-selective extraction chromatographic resin. Solvent Extraction Ion Exchange 10, 313-336.

Hossain M., Aminul Islam A. T. M., and Kumar Saha S. (1987) Floods in Bangladesh. Universities Research Centre.

Hurtrez J.-E. (1998) Analyse géomorphologique des interactions Tectonique-Erosion dans le système Himalayen. Thèse de l'Université de Montpellier II.

Kotarba M., Sokolowski A., and Bogacz W. (1981) Hydrogeological investigations in the Kali Gandaki thermal springs area (Nepal Himalayas). Bulletin of the Polish Academy of Sciences, Earth Sciences 29, 283-291.

Krishnaswami S., Trivedi J. R., Sarin M. M., Ramesh R., and Sharma K. K. (1992) Strontium isotopes and rubidium in the Ganga-Brahmaputra river system: Weathering in the Himalaya, fluxes to the Bay of Bengal and contributions to the evolution of oceanic ${ }^{87} \mathrm{Sr} /{ }^{86} \mathrm{Sr}$. Earth Planet. Sci. Lett. 109, 243-253.

Le Fort P. (1989) The Himalayan orogenic segment. In Tectonic evolution of the Tethyan regions. Proceedings of the NATO ASI meeting, Istanbul, October 1985. (ed. A. M. C. Sengör).

Le Fort P. and France-Lanord C. (1995) Granites from Mustang and surrounding regions. Journal of Nepal Geological Society 11, 53-57.

Louvat P. (1997) Etude géochimique de l'érosion fluviale d'îles volcaniques à l'aide des bilans d'éléments majeurs et traces. Thèse de l'Université de Paris VII.

Mingsen L. (1981) Soil formation and distribution on Qiangtang plateau. Geological and Ecological Studies of Qinghai-Xizang Plateau, 1877-1896.

Moore W. S. (1997) High fluxes of radium and barium from the mouth of the GangesBrahmaputra River diring low river discharge suggest a large groundwater source. Earth Planet. Sci. Lett. 150, 141-150. 
Ohr M., Halliday A. N., and Peacor D. R. (1994) Mobility and fractionation of rare earth elements in argillaceous sediments; implications for dating diagenesis and low-grade metamorphism. Geochim. Cosmochim. Acta 58, 1289-1312.

Palmer M. R. and Edmond J. M. (1989) The strontium isotope budget of the modern ocean. Earth Planet. Sci. Lett. 92, 11-26.

Palmer M. R. and Edmond J. M. (1992) Controls over the strontium isotope composition of river water. Geochim. Cosmochim. Acta 56, 2099-2111.

Plummer L. N. and Mackenzie F. T. (1974) Predicting mineral solubility from rate data:application to the dissolution of magnesian calcites. Amer. J. Sci. 274, 61-83.

Quade J., Roe L., DeCelles P. G., and Ojha T. P. (1997) The late Neogene ${ }^{87} \mathrm{Sr} /{ }^{86} \mathrm{Sr}$ record of lowland Himalayan rivers. Science 276, 1828-1831.

Raymo M. E. and Ruddiman W. F. (1992) Tectonic forcing of late Cenozoic climate. Nature 359, 117-122.

Reeve A. S. and Perry E. C. (1994) Carbonate geochemistry and the concentrations of aqueous $\mathrm{Mg}^{2+}, \mathrm{Sr}^{2+}$ and $\mathrm{Ca}^{2+}:$ Western north coast of the Yucatan, Mexico. Chem. Geol. 112, 105-117.

Richter F. M., Rowley D. B., and DePaolo D. J. (1992) Sr isotope evolution of seawater: the role of tectonics. Earth Planet. Sci. Lett. 109, 11-23.

Sarin M. M., Krishnaswami S., Dilli K., Somayajulu B. L. K., and Moore W. S. (1989) Major ion chemistry of the Ganga-Brahmaputra river system: Weathering processes and fluxes to the Bay of Bengal. Geochim. Cosmochim. Acta 53, 997-1009.

Sarkar A., Roy A., Ghatak G. S., and Bhattacharya S. K. (1996) Strontium isotope study of Krol-Tal carbonates: Implication to the Strontium isotope flux of Himalayan rivers. Ind. J. Geol. 68, 255-262.

Sheppard S. M. F. and Schwarcz H. P. (1970) Fractionation of carbon and oxygen isotopes and magnesium between coexisting metamorphic calcite and dolomite. Contrib. Mineral. Petrol. 26, 161-198.

Singh S. K., Trivedi J. R., Pande K., Ramesh R., and Krishnaswami S. (1998) Chemical and $\mathrm{Sr}, \mathrm{O}, \mathrm{C}$, isotopic compositions of carbonates from the Lesser Himalaya: Implications to the Sr isotope composition of the source waters of the Ganga, Ghaghara and the Indus Rivers. Geochim. Cosmochim. Acta 62, 743-755.

Stallard R. F. and Edmond J. M. (1983) Geochemistry of the Amazon: The influence of geology and weathering environnement on the dissolved load. J. Geophys. Res. 88, 96719688.

Stoll H. M. and Schrag D. P. (1998) Effects of Quaternary sea level cycles on strontium in 
Trivedi J. R., Gopalan K., and Valdiya K. S. (1984) Rb-Sr ages of granitic rocks within the Lesser Himalayan nappes, Kumaun, India. J. Geol. Soc. India 25, 641-654.

Trivedi J. R., Pande K., Krishnaswami S., and Sarin M. M. (1995) Sr isotopes in rivers of India and Pakistan: a reconnaissance study. Curr. Sci. 69, 171-178.

Upreti B. N. and Le Fort P. (in press) Lesser Himalayan crystalline nappes of Nepal: problems of their origin. In Himalaya and Tibet: mountain roots to mountain tops, Vol. 328 (ed. A. Macfarlane, R. B. Sorkhabi, and J. Quade). GSA special paper.

Von Rad U., Dürr S. B., Ogg J. G., and Wiedmann J. (1994) The Triassic of the Thakkhola (Nepal). I: stratigraphy and paleoenvironment of a north-east Gondwanan rifted margin. Geol. Rundsch. 83, 76-106.

Wake C. P., Mayewski P. A., Zichu X., Ping W., and Zhongqin L. (1993) Regional distribution of monsoon and desert dust signals recorded in Asian glaciers. Geophys. Res. Lett. 30, 1411-1414.

Webster J. G., Brown K. L., and Vincent W. F. (1994) Geochemical processes affecting meltwater chemistry and the formation of saline ponds in the Victoria Valley and Bull Pass region, Antartica. Hydrobiologia 281, 171-186.

Zeng Mianping e. a. (1989) Saline lake on the Qinghai-Xizang (Tibet) plateau. Beijing scientific and technical publishing house. 


\section{Figure captions}

Fig. 1 : Map of the Ganges and Brahmaputra basin and location of river samples and maps of figure 2. When several samples were taken at the same location only the first sample is labelled on the map. MFT: the Main Frontal Thrust places Mio-Pliocene Siwalik foreland basin sediments over the modern Gangetic plain. MCT : the Main Central Thrust places the HHC over the LH.

Fig. 2 : Geological maps of (a) Narayani watershed and (b) Karnali watershed. River water samples are marked by a circle and reference source rock samples by a square. When several samples have been taken at the same location only the first sample is labelled on the map. Geology after Colchen et al., (1986); Le Fort and France-Lanord, (1995) and Upreti and Le Fort, (in press). TSS = Tethyan Sedimentary Series. HHC = High Himalaya Crystalline. LH = Lesser Himalaya. HHL = High Himalaya Leucogranite. LHN = Lesser Himalayan Nappe.

Fig 3 : Isotopic composition of dissolved $\mathrm{Sr}$ versus $1 /[\mathrm{Sr}]$. Samples with watershed in the TSS, HHC, LH and Siwaliks are individualised. All other samples are rivers combining drainage of several geological formations in Nepal and Bangladesh. The shaded area corresponds to published data for Himalayan tributaries of G-B (Krishnaswami et al., 1992; Palmer and Edmond, 1992; Trivedi et al., 1995; Harris et al., 1998). The two lines bracket the riverine composition of dissolved $\mathrm{Sr}$ in other major world rivers (Edmond, 1992).

Fig 4 : River profile of the Kali Gandaki, from the source in the Mustang graben to the outflow of the Narayani in the Gangetic plain. a) Topographic profile of the river and average crest altitude (Hurtrez, 1998). The breaks in slope of the river profile underline the zones of intense physical erosion. Rocks of the Tethyan Sedimentary Series (TSS) are separated from the High Himalayan Crystalline sequence (HHC) by the Southern Tibetan Detachment System (STDS). The HHC are thrusted over the Lesser Himalaya (LH) along the Main Central Thrust (MCT). b) River flux as calculated from integration of 1987-90 precipitation data over the basin (Hurtrez, 1998). The circle indicate gaged data from Hydrological survey of Nepal. c) ${ }^{87} \mathrm{Sr} /{ }^{86} \mathrm{Sr}$ of dissolved $\mathrm{Sr}$ (closed symbols) and riverine $\mathrm{Sr}$ fluxes (open triangle) calculated from $[\mathrm{Sr}]$ in Table 1 and water flux.

Fig 5 : Isotopic composition of $\mathrm{Sr}$ versus 1/[Sr] in bedrock and bedload carbonate samples. The LH data from central Nepal reflect Sr loss and exchange during metamorphism. TSS and 
bedload carbonate in the main rivers and in the Ganges and Brahmaputra is consistent with the admixture of TSS-HHC carbonate with the highly radiogenic carbonate end member from the LH, as represented by sample AP 74-207. The less radiogenic LH carbonate does not contribute significantly to the bed load.

Fig 6 : Variation of dissolved $\mathrm{Na} / \mathrm{Sr}$ molar ratio with $\mathrm{X}_{\mathrm{Ca}}$ (eq\%) for rivers draining basin of silicate composition (except Langtang samples). All data are corrected for rain water contribution. Dissolution of discrete carbonate present in altered formations is sufficient in some cases to significantly increase $\mathrm{X}_{\mathrm{Ca}}$ and [Sr]. The shaded zone indicate $\mathrm{X}_{\mathrm{Ca}}$ value for HHC plagioclase after Brouand, (1989).

Fig 7 : Estimate of the average contribution of Sr sources to river chemistry in TSS, HHC, LH and Siwalik catchments. LH and HHC rivers are characterized by low [Sr] compared to TSS and Siwaliks rivers. Siwaliks rivers are characterized by a very high proportion of Sr derived from silicate alteration.

Fig 8 : Isotopic composition of $\mathrm{Sr}$ versus 1/[Sr] for (a) the Narayani and its principal tributaries in Lesser Himalaya (b) main Himalayan rivers from other basins; (c) flood plain and delta waters. Average and standard deviation for small rivers in each Himalayan geological unit (TSS, HHC and LH and Siwaliks) have been represented according to data in figure 4. Composition lines for waters with $25 \%$ and $50 \%$ of their Sr derived from the TSS are shown for a mixing between TSS, HHC and LH. Data are from this study; Krishnaswami et al., (1992); Palmer and Edmond, (1989); Palmer and Edmond, (1992); Trivedi et al., (1995) and Harris et al., (1998).

Fig 9 : Origin of $\mathrm{Sr}$ in term of lithologies for the Narayani and its two main tributaries. This budget derives from $\mathrm{Sr}$ isotopic mass balance (Fig. 8a) combined with lithological budget for each geological unit (Fig. 7).

Fig. 10 : Ca versus Sr concentration relationship for Ganges (square) and Brahmaputra (circle) near their mouth. Data are from this study; Palmer and Edmond (1989) and Sarin et al., (1989). ${ }^{87} \mathrm{Sr} / 86 \mathrm{Sr}$ values for each sample are indicated. During the monsoon, waters are more radiogenic and less concentrated. Based on this relationship and on the [Ca] yearly average given by the GEMS water program (arrows), average [Sr] for the Ganges and Brahmaputra should be 0.75 and $0.2 \mu \mathrm{mol} / 1$ respectively. 
Fig. 11 : Schematic evolution diagram for ${ }^{87} \mathrm{Sr} /{ }^{86} \mathrm{Sr}$ in seawater, assuming present day values of $\mathrm{R}_{\mathrm{R}}=0.7114, \mathrm{~J}_{\mathrm{R}}=32.02 \times 10^{9} \mathrm{~mol} / \mathrm{yr} ; \mathrm{R}_{\mathrm{D}}=0.7084, \mathrm{~J}_{\mathrm{D}}=3.4 \times 10^{9} \mathrm{~mol} / \mathrm{yr} ; \mathrm{R}_{\mathrm{GB}}=0.7295$, $\mathrm{J}_{\mathrm{GB}}=0.68 \times 10^{9} \mathrm{~mol} / \mathrm{yr}$; and $\mathrm{R}_{\mathrm{H}}=0.7035$. The horizontal line represents steady state $\left(\mathrm{dR}_{\mathrm{SW}} / \mathrm{dt}\right.$ $=0$ ). The mean Pleistocene slope of $54 \times 10^{-6} \mathrm{Ma}^{-1}$ is calculated from Hodell et al., 1992, which defines a $\mathrm{J}_{\mathrm{H}}$ of $13.2 \times 10^{9} \mathrm{~mol} / \mathrm{yr}$. The "step" history has the same mean slope and is indistinguishable at present analytical resolution, but is farther from steady state during "interglacial" conditions (given by modern values), and at steady state during glacial conditions with all river fluxes set to $75 \%$ of modern values. The step model defines a $\mathrm{J}_{\mathrm{H}}$ of $10.7 \times 10^{9}$ $\mathrm{mol} / \mathrm{yr}$. The negative slope is calculated for a modern world with $\mathrm{J}_{\mathrm{H}}$ of $13.2 \times 10^{9} \mathrm{~mol} / \mathrm{yr}$, but no flux from the G-B system. The change in slope that results from the hypothetical removal of the G-B flux demonstrates the strong control the G-B system has on the rate of change of the seawater ${ }^{87} \mathrm{Sr} /{ }^{86} \mathrm{Sr}$ value. 







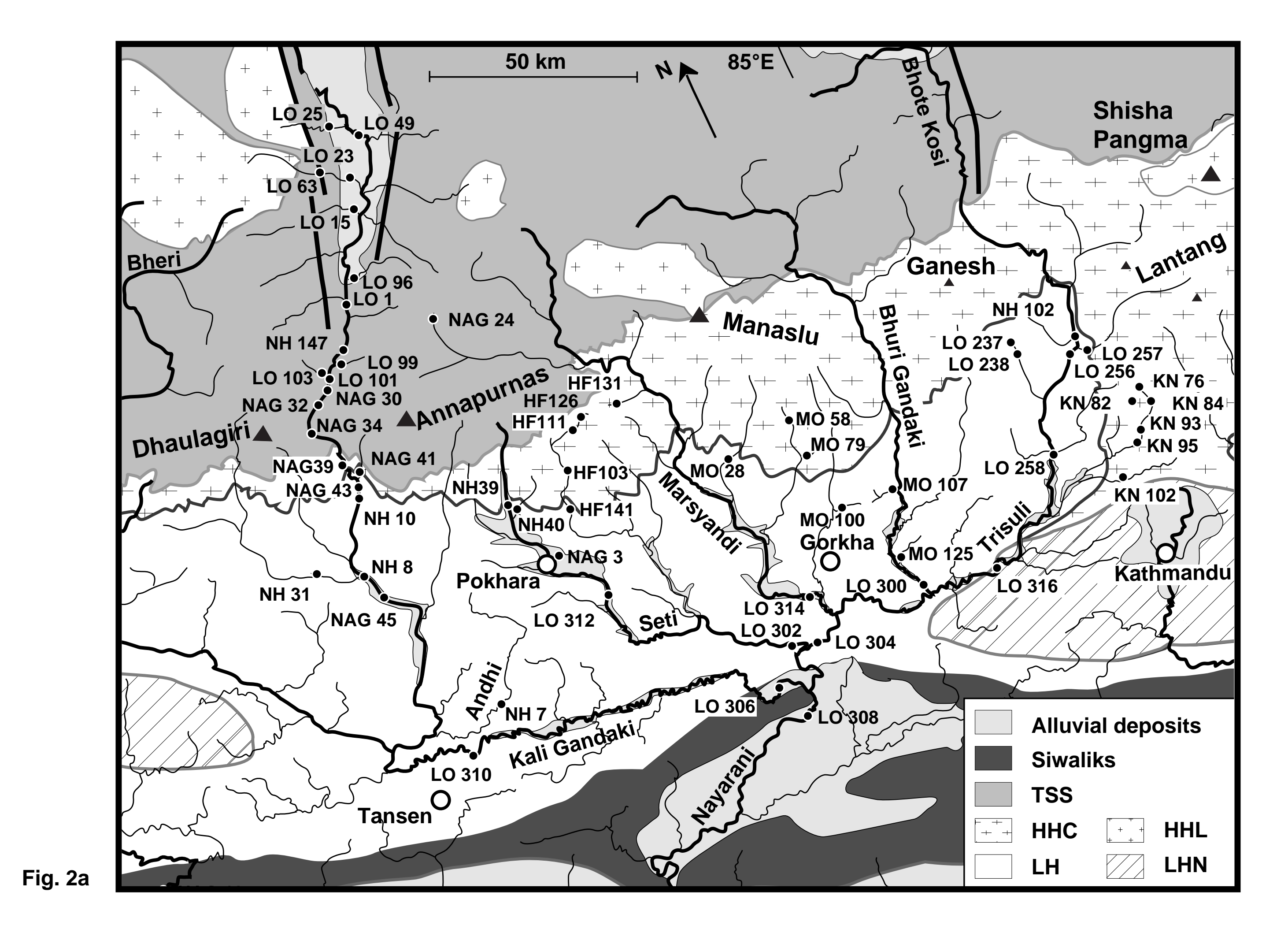




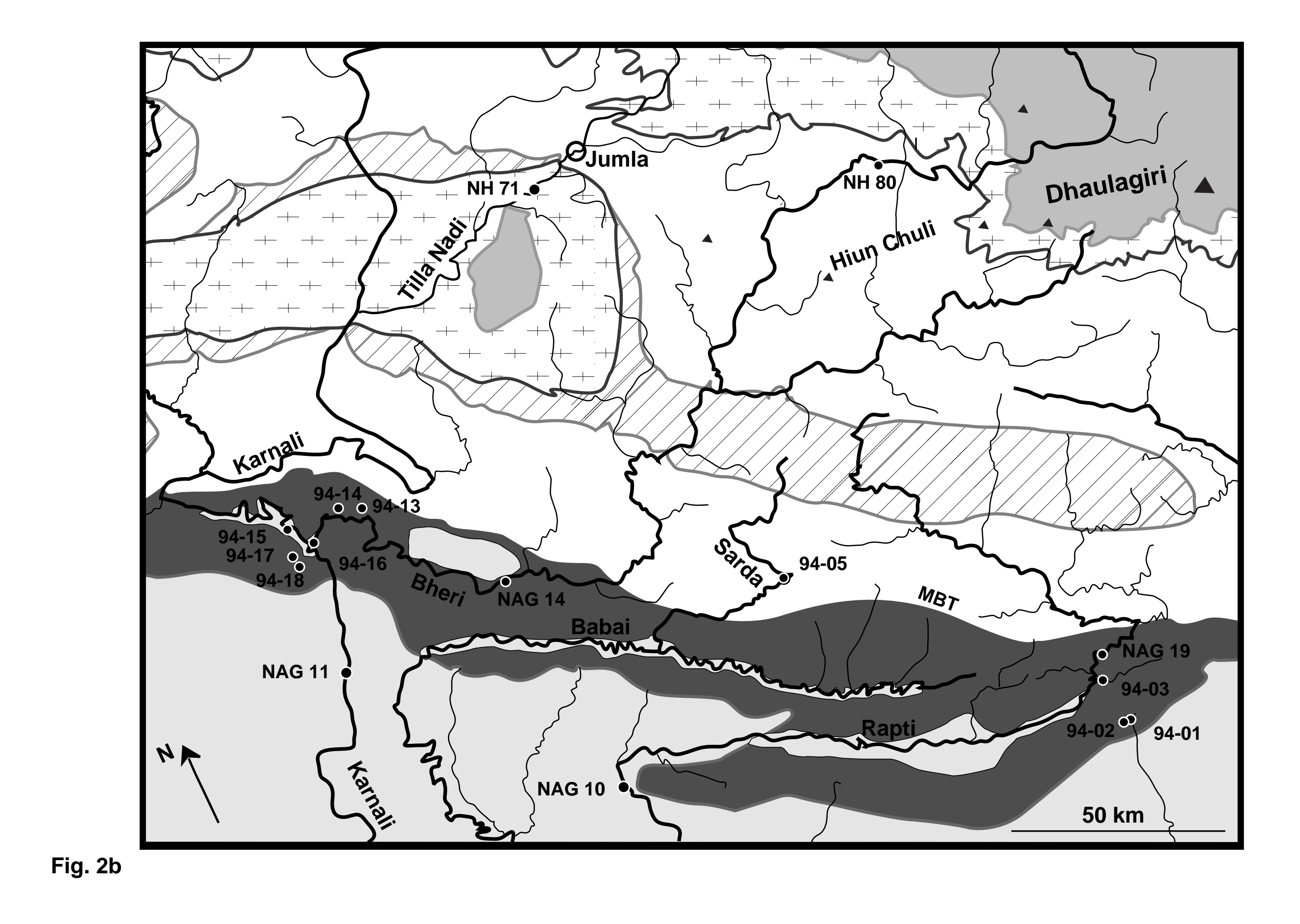


Galy et al.

Fig. 3

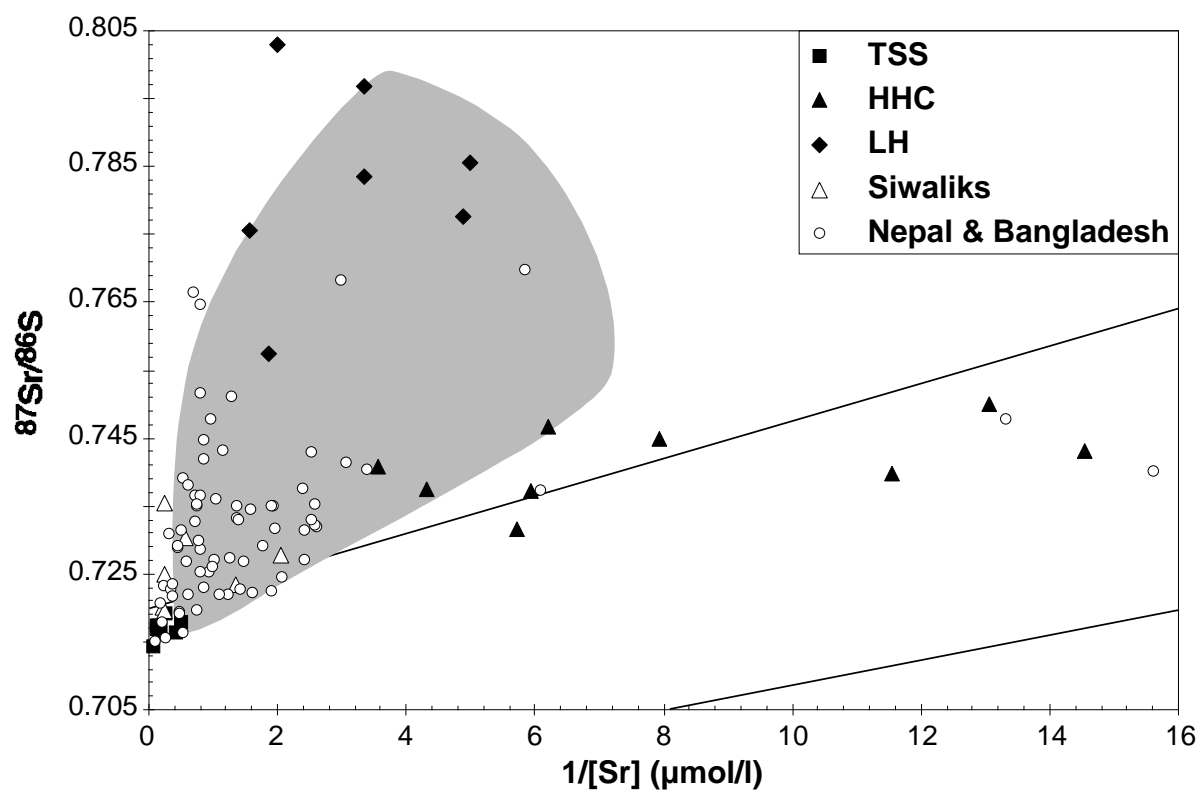


Galy et al.

Fig. 4
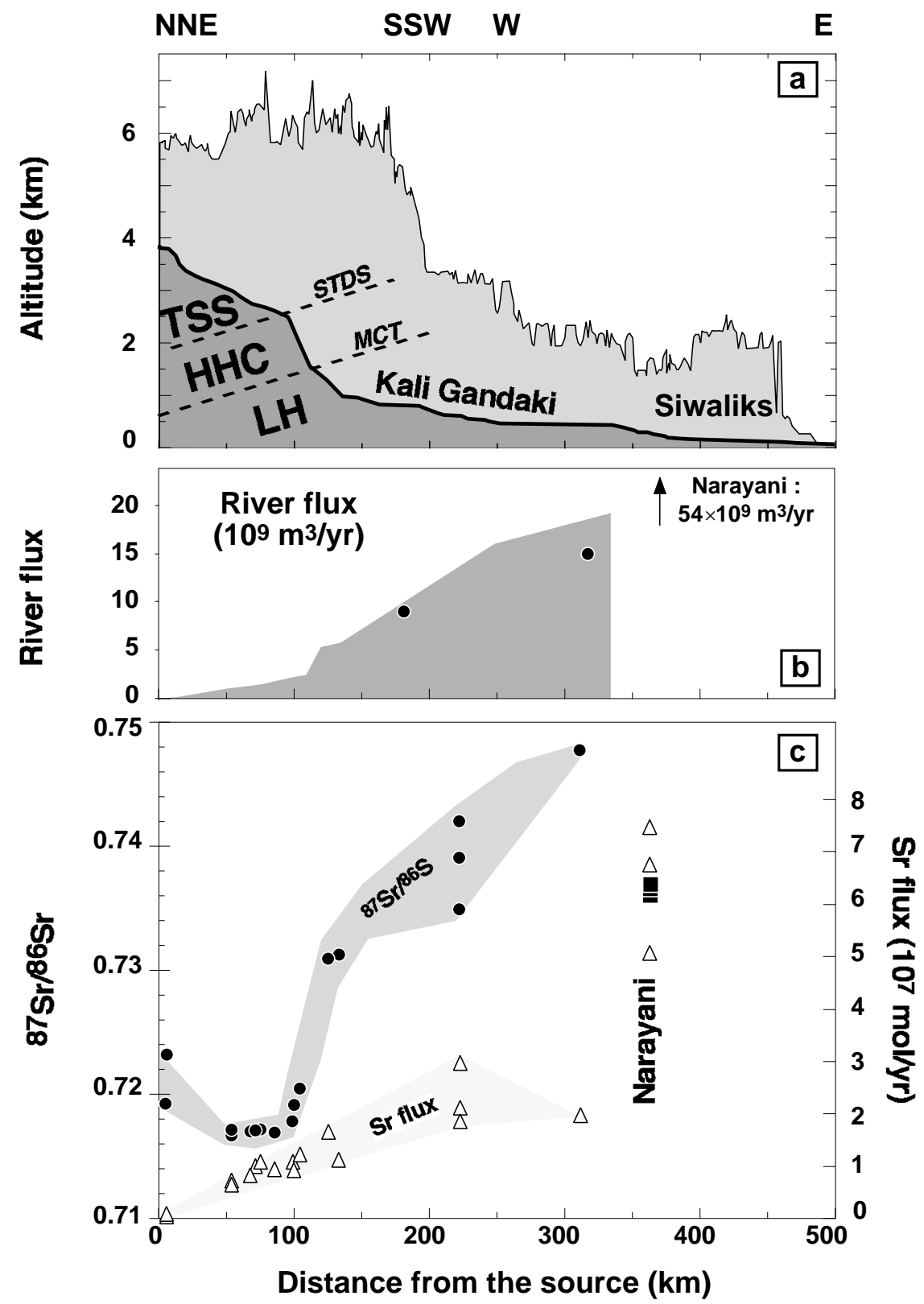
Galy et al.

Fig. 5

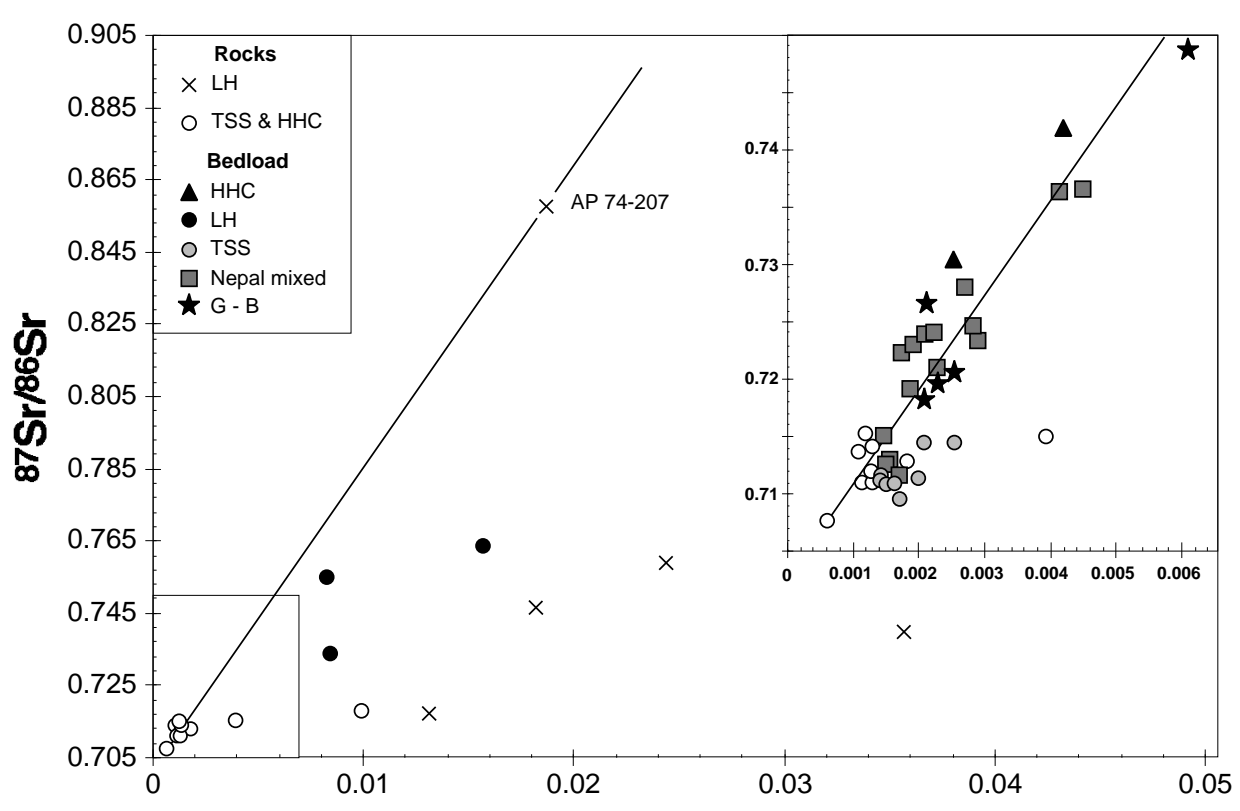

\section{$1 /[\mathrm{Sr}](\mathrm{ppm})$}

Galy et al.

Fig. 6

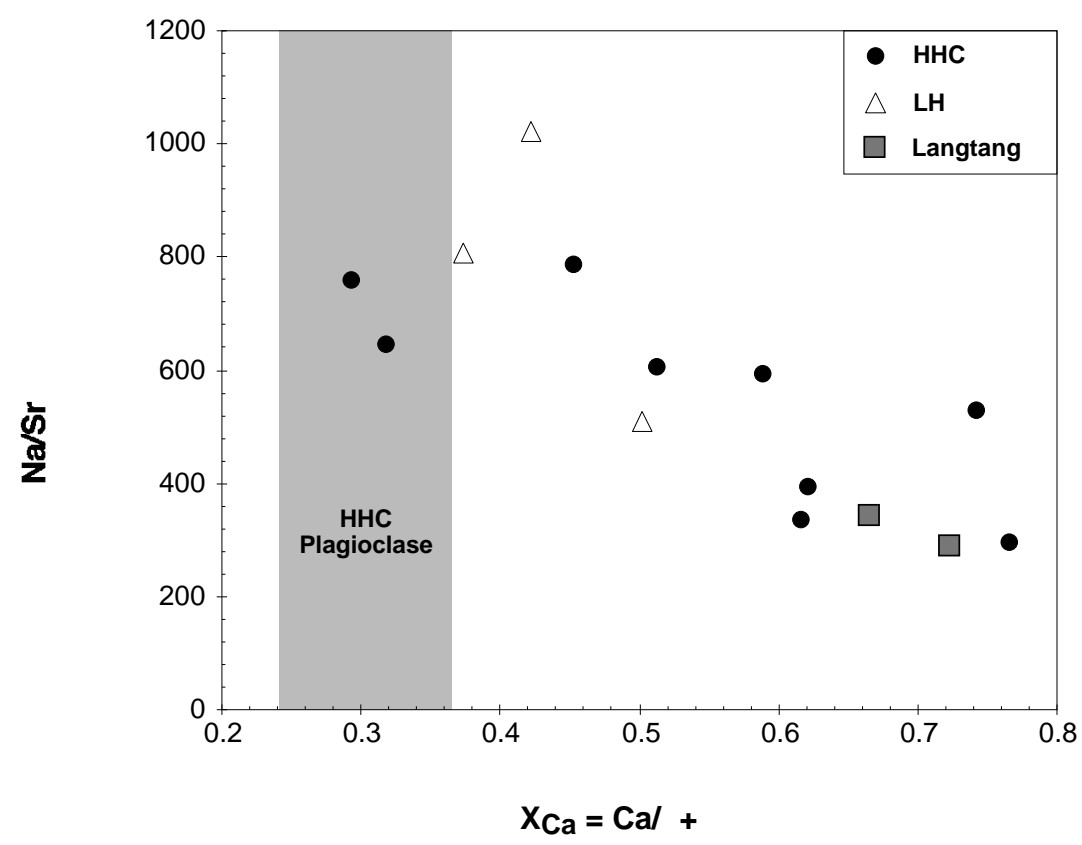


Galy et al.

Fig.7

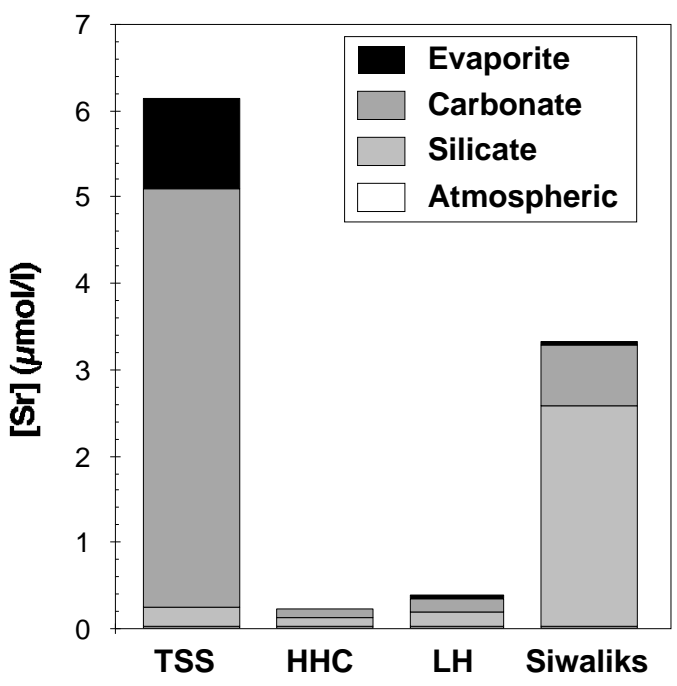


Galy et al.

Fig. 8
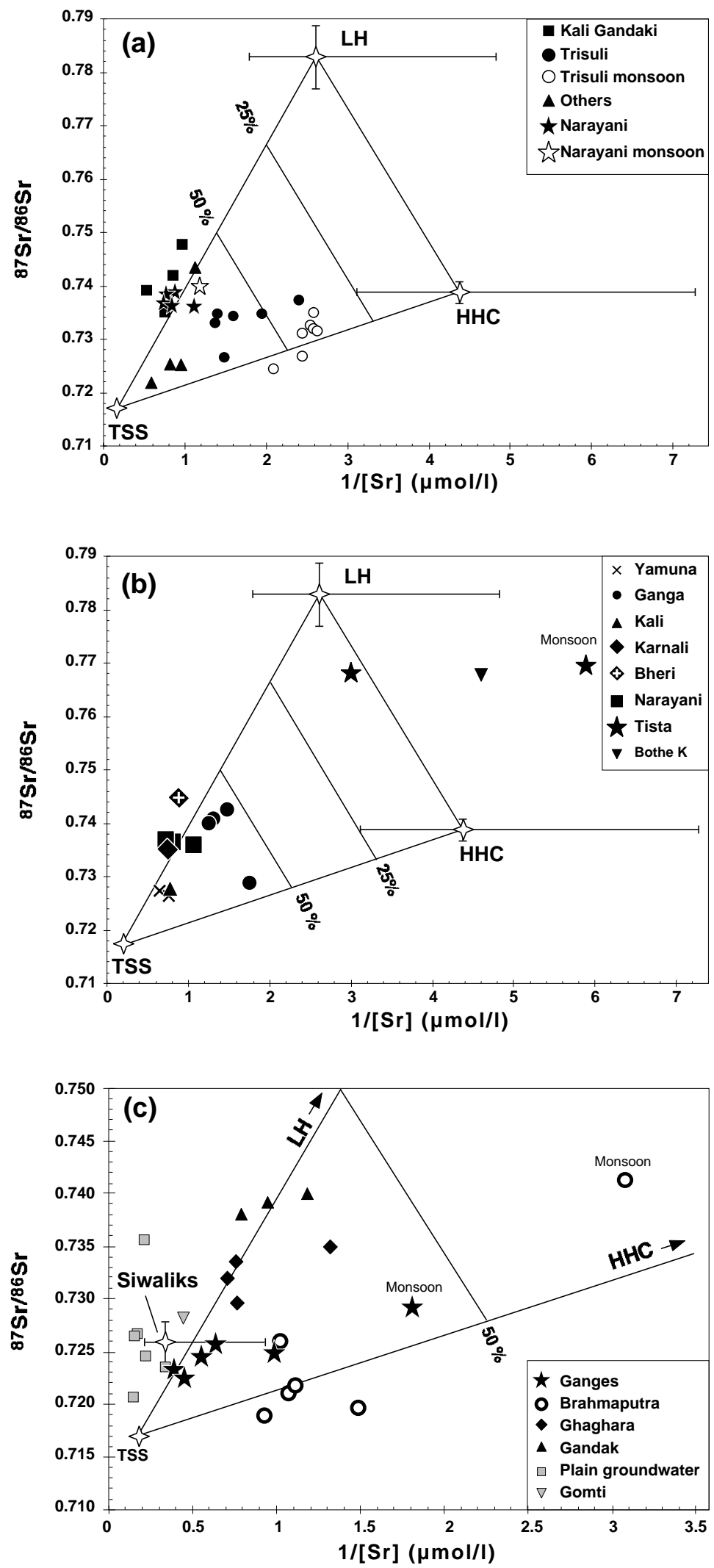
Galy et al.

Fig. 9

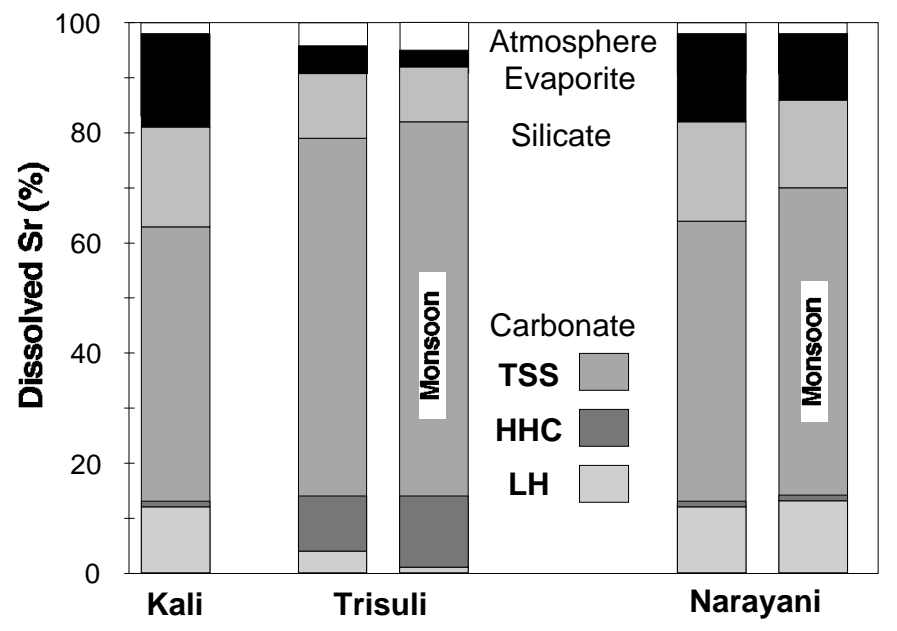


Galy et al.

Fig. 10

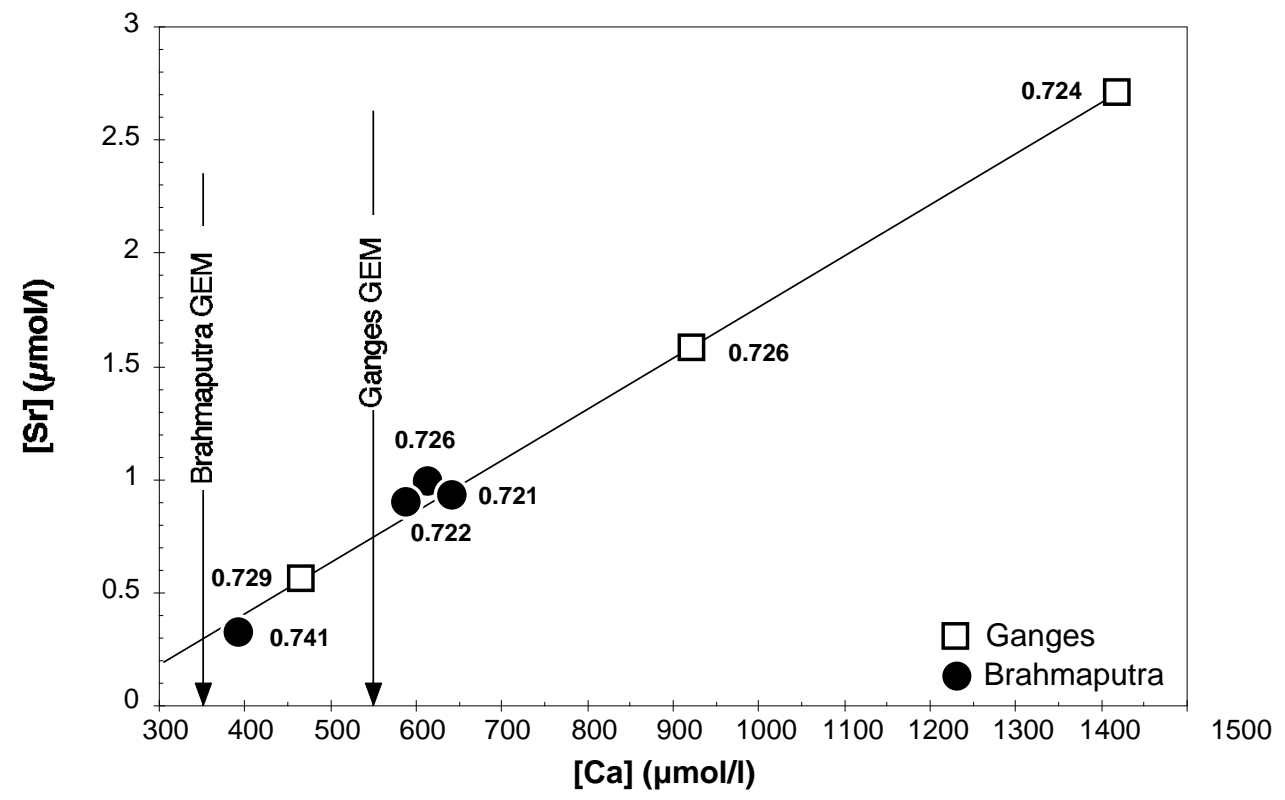

Galy et al.

Fig. 11

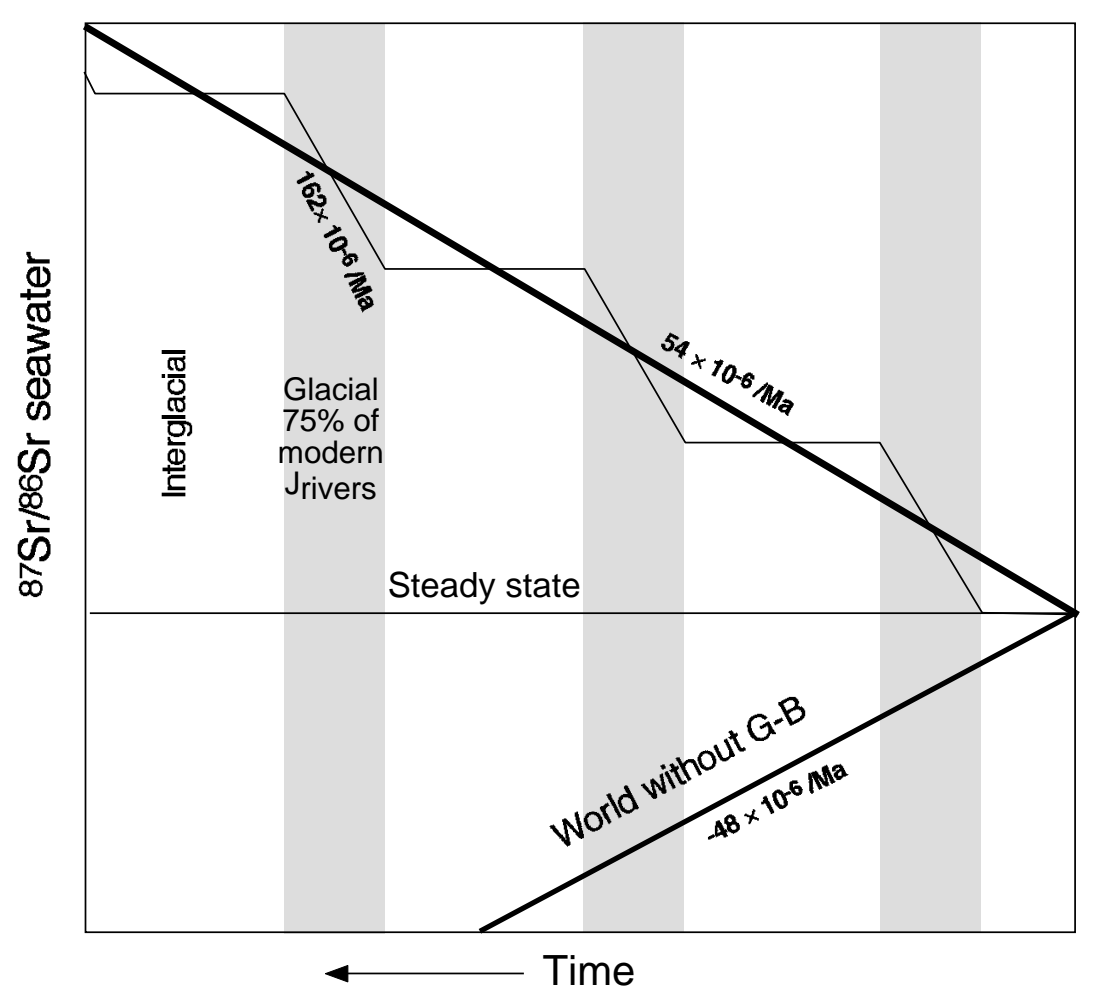


Table 1 - Chemical data from the Kali Gandaki and tributaries

\begin{tabular}{|c|c|c|c|c|c|c|c|c|}
\hline Sample & River & Location & Date & Unit & $\begin{array}{c}\text { Altitud } \\
\mathrm{m}\end{array}$ & $\begin{array}{l}\text { TDS } \\
\mathrm{mg} / 1\end{array}$ & $\begin{array}{l}\mathrm{Sr}^{2+} \\
\mu \mathrm{mol} /\end{array}$ & ${ }^{87} \mathrm{Sr} / 86 \mathrm{Sr}$ \\
\hline LO 25 & Nangyal & Lo Mantang & 20.may.93 & & 3695 & 161 & 0.80 & 0.7218 \\
\hline LO 49 & Kali & Lo Mantang & 20.may.93 & & 3550 & 316 & $4.25^{\#}$ & 0.7232 \\
\hline NH 133 & Kali & Lo Mantang & 30.apr.95 & & 3575 & 218 & 2.01 & 0.7193 \\
\hline LO 63 & Tsarang & Lo Gekar & 21.may.93 & & 3920 & 212 & 1.90 & 0.7162 \\
\hline LO 23 & Tsarang & Tsarang & 19.may.93 & & 3400 & 394 & $3.71^{\#}$ & 0.7155 \\
\hline LO 15 & Ghemi & Ghemi & 19.may.93 & & 3385 & 214 & $2.32^{\#}$ & 0.7162 \\
\hline LO 96 & Narsing & Chhuksang & 24.may.93 & & 2900 & 880 & 11.1 & 0.7143 \\
\hline LO 1 & Kali & Kagbeni & 16.may.93 & TSS & 2800 & 358 & $6.06^{\#}$ & 0.7171 \\
\hline NAG 21 & Kali & Kagbeni & 25.nov.95 & TSS & 2790 & 426 & $5.41^{\#}$ & 0.7166 \\
\hline NH 147 & Kali & Jomsom & 03.may.95 & TSS & 2675 & 400 & 6.57 & 0.7173 \\
\hline LO 99 & Thini & Thinigaon & 26.may.93 & TSS & 2650 & 293 & 3.87 & 0.7192 \\
\hline LO 103 & Marpha & Marpha & 26.may.93 & TSS & 2635 & 183 & 1.93 & 0.7177 \\
\hline LO 101 & Kali & Marpha & 26.may.93 & TSS & 2530 & 348 & $5.60^{\#}$ & 0.7171 \\
\hline NAG 30 & Kali & Chairogaon & 01.dec.95 & TSS & 2626 & 418 & 6.89 & 0.7169 \\
\hline NAG 32 & Kali & Khobang & 02.dec.95 & TSS & 2530 & 416 & 6.77 & 0.7173 \\
\hline NAG 34 & Kali & Koketani & 02.dec.95 & TSS & 2500 & 382 & 5.60 & 0.7168 \\
\hline NAG 39 & Kali & Dana & 03.dec.95 & & 1450 & 361 & $4.59^{\#}$ & 0.7177 \\
\hline NAG 41 & Miristi & Banskot & 04.dec.95 & & 1490 & 165 & 1.31 & 0.7197 \\
\hline NH 10 & Kali & Tatopani & 15.mar.95 & & 1180 & 362 & 4.99 & 0.7205 \\
\hline NAG 43 & Kali & Tatopani & 05.dec.95 & & 1180 & 314 & $3.72^{\#}$ & 0.7190 \\
\hline NH 31 & Mayongdi & Tatopani & 14.mar.95 & & 905 & 256 & 1.44 & 0.7663 \\
\hline NH 8 & Kali & Beni & 13.mar.95 & & 815 & 290 & 3.09 & 0.7310 \\
\hline NAG 45 & Kali & Baglung & 6.dec.95 & & 740 & 231 & $1.94^{\#}$ & 0.7313 \\
\hline NH 7 & Andhi & Waling & 12.mar.95 & $\mathrm{LH}$ & 705 & 269 & 0.30 & 0.7846 \\
\hline LO 310 & Kali & Ramdi & 10.jun.93 & & 460 & 186 & $1.31^{\#}$ & 0.7350 \\
\hline NH 6 & Kali & Ramdi & 12.mar.95 & & 460 & 264 & 1.85 & 0.7391 \\
\hline NAG 5 & Kali & Ramdi & 13.nov.95 & & 460 & 206 & 1.16 & 0.7419 \\
\hline LO 306 & Kali & Kot & 09.jun.93 & & 305 & 162 & $1.02^{\#}$ & 0.7477 \\
\hline
\end{tabular}

\# : AA analysis calibrated with MSID 
Table 2 - Chemical data from the Trisuli river and tributaries

\begin{tabular}{|c|c|c|c|c|c|c|c|c|}
\hline Sample & River & Area & Date & Unit & Altitude & $\begin{array}{l}\mathrm{TDS} \\
\mathrm{mg} / \mathrm{l}\end{array}$ & $\begin{array}{l}\mathrm{Sr}^{2+} \\
\mu \mathrm{mol} / \mathrm{l}\end{array}$ & ${ }^{87} \mathrm{Sr} /{ }^{86} \mathrm{Sr}$ \\
\hline LO 237 & Lari & Lari valley & 05.jun.93 & & 4245 & 40 & $0.06^{\#}$ & 0.7400 \\
\hline LO 238 & Mailung & Paigutang & 05.jun.93 & & 4020 & 18 & 0.08 & 0.7476 \\
\hline LO 257 & Langtang & Syabru Bensi & 06.jun.93 & & 1480 & 33 & 0.16 & 0.7371 \\
\hline NH 100 & Langtang & Syabru Bensi & 14.apr.95 & & 1455 & 50 & 0.29 & 0.7403 \\
\hline NH 102 & Bhote Kosi & Syabru Bensi & 14.apr.95 & & 1440 & 128 & 1.14 & 0.7229 \\
\hline LO 256 & Bhote Kosi & Syabru Bensi & 06.jun.93 & & 1440 & 79 & 0.62 & 0.7222 \\
\hline LO 258 & Trisuli & Betrawati & 06.jun.93 & & 750 & 73 & 0.67 & 0.7268 \\
\hline TRI 19/6 & Trisuli & Betrawati & 19.jun.93 & & 750 & 63 & 0.41 & 0.7270 \\
\hline TRI 6/7 & Trisuli & Betrawati & 06.jul.93 & & 750 & 71 & 0.38 & 0.7318 \\
\hline TRI 15/7 & Trisuli & Betrawati & 15.jul.93 & & 750 & 81 & 0.48 & 0.7246 \\
\hline TRI 1/8 & Trisuli & Betrawati & 01.aug.93 & & 750 & 73 & 0.41 & 0.7313 \\
\hline TRI 15/8 & Trisuli & Betrawati & 15.aug.93 & & 750 & 70 & 0.39 & 0.7321 \\
\hline TRI 1/9 & Trisuli & Betrawati & $01 . s e p .93$ & & 750 & 68 & 0.39 & 0.7328 \\
\hline TRI 15/9 & Trisuli & Betrawati & 15. sep.93 & & 750 & 60 & 0.39 & 0.7353 \\
\hline TRI 1/10 & Trisuli & Betrawati & 01. oct.93 & & 750 & 64 & 0.42 & 0.7375 \\
\hline TRI $15 / 10$ & Trisuli & Betrawati & 15. oct. 93 & & 750 & 79 & 0.51 & 0.7349 \\
\hline TRI 1/11 & Trisuli & Betrawati & 01.nov.93 & & 750 & 80 & 0.52 & 0.7349 \\
\hline TRI 1/12 & Trisuli & Betrawati & 01.dec.93 & & 750 & 95 & 0.63 & 0.7345 \\
\hline TRI 4/4 & Trisuli & Betrawati & 04.apr.94 & & 750 & 107 & 0.73 & 0.7331 \\
\hline $\mathrm{KN} 76^{\mathrm{S}}$ & Tadi & Source & 21.mar.94 & $\mathrm{HHC}$ & 3665 & 11 & 0.08 & 0.7500 \\
\hline $\mathrm{KN} 82^{\mathrm{S}}$ & Hundi & Shisipur & 21.mar.94 & $\mathrm{HHC}$ & 2130 & 12 & 0.09 & 0.7397 \\
\hline $\mathrm{KN} 84^{\mathrm{S}}$ & Tadi & Ghyangphedi & 21.mar.94 & $\mathrm{HHC}$ & 2050 & 32 & 0.18 & 0.7315 \\
\hline $\mathrm{KN} 93^{\mathrm{S}}$ & Tadi & Satbise & 23.mar.94 & $\mathrm{HHC}$ & 945 & 27 & 0.17 & 0.7373 \\
\hline $\mathrm{KN} 95^{\mathrm{S}}$ & Chake & Samundratar & 23.mar.94 & $\mathrm{HHC}$ & 935 & 30 & 0.23 & 0.7376 \\
\hline $\mathrm{KN} 102^{\mathrm{S}}$ & Likhu & Bhadrutar & 24.mar.94 & $\mathrm{HHC}$ & 750 & 55 & 0.28 & 0.7407 \\
\hline LO 316 & Trisuli & Adamghat & 10.jun.93 & & 465 & 84 & $0.72^{\#}$ & 0.7348 \\
\hline LO 304 & Trisuli & Gumaune & 09.jun.93 & & 320 & 115 & $0.97^{\#}$ & 0.7270 \\
\hline
\end{tabular}

\# : AA analysis calibrated with MSID. S : Silicated catchment 
Table 3 - Chemical data for other rivers of the Narayani basin.

\begin{tabular}{|c|c|c|c|c|c|c|c|c|}
\hline Sample & River & Location & Date & Unit & $\begin{array}{c}\text { Altitude } \\
\mathrm{m}\end{array}$ & $\begin{array}{l}\mathrm{TDS} \\
\mathrm{mg} / \mathrm{l}\end{array}$ & $\begin{array}{c}\mathrm{Sr}^{2+\varepsilon} \\
\mu \mathrm{mol} / 1\end{array}$ & ${ }^{87} \mathrm{Sr} /{ }^{86} \mathrm{Sr}$ \\
\hline \multicolumn{9}{|c|}{ BHURI GANDAKI } \\
\hline MO $107^{\mathrm{S}}$ & Mati & Arughat & 12.may.97 & $\mathrm{LH}$ & & 78 & 0.50 & 0.8030 \\
\hline MO 110 & Isul & Arughat & 12.may.97 & LH & & 297 & 0.64 & 0.7756 \\
\hline MO $125^{\mathrm{S}}$ & Sueli & & 14.may.97 & $\mathrm{LH}$ & & 49 & 0.20 & 0.7855 \\
\hline LO 300 & Bhuri Gandaki & Benighat & 09.jun.93 & & 410 & 122 & $1.07^{\#}$ & 0.7252 \\
\hline \multicolumn{9}{|c|}{ MARSYANDI } \\
\hline NAG 24 & Marsyandi & source & 28.nov.95 & TSS & 5050 & 606 & 10.3 & 0.7150 \\
\hline MO $58^{\mathrm{S}}$ & Chepe & & 07.may.97 & $\mathrm{HHC}$ & 3100 & 17 & 0.07 & 0.7431 \\
\hline MO $79^{S}$ & Khota & & 09.may.97 & $\mathrm{HHC}$ & 1700 & 42 & 0.13 & 0.7449 \\
\hline $\mathrm{MO} 84^{\mathrm{S}}$ & Chepe & & 09.may.97 & $\mathrm{HHC}$ & & 32 & 0.16 & 0.7468 \\
\hline MO $100^{\mathrm{S}}$ & Marsel & & 11.may.97 & $\mathrm{LH}$ & 590 & 55 & 0.30 & 0.7969 \\
\hline LO 314 & Marsyandi & Markichok & 10.jun.93 & & 435 & 127 & $1.24^{\#}$ & 0.7253 \\
\hline \multicolumn{9}{|c|}{ SETI KHOLA } \\
\hline HF 141 & Madi & Khilang & 10.may.93 & & 1040 & 102 & 0.53 & 0.7224 \\
\hline NH 40 & Sardi & Khadarjung & 16.mar.95 & & 1185 & 133 & 0.39 & 0.7429 \\
\hline NH 39 & Seti & Khadarjung & 16.mar.95 & & 1180 & 208 & 2.03 & 0.7192 \\
\hline NAG 3 & Bijaipur & Kundahar & 11.nov.95 & $\mathrm{LH}$ & 870 & 149 & 0.54 & 0.7575 \\
\hline LO 312 & Seti & Kotre Bazar & 10.jun.93 & & 585 & 179 & $1.58^{\#}$ & 0.7218 \\
\hline LO 302 & Seti & Sarang Ghat & 09.jun.93 & & 325 & 162 & $0.86^{\#}$ & 0.7430 \\
\hline \multicolumn{9}{|c|}{ NARAYANI } \\
\hline LO 308 & Narayani & Nayaran Ghat & 09.jun.93 & & 225 & 145 & $0.94^{\#}$ & 0.7360 \\
\hline NH 1 & Narayani & Nayaran Gha & 10.mar.95 & & 225 & 202 & 1.39 & 0.7365 \\
\hline NAG 49 & Narayani & Nayaran Gha & 11.dec.95 & & 225 & 207 & 1.25 & 0.7364 \\
\hline
\end{tabular}

\# : AA analysis calibrated with MSID. S : Silicated catchment 
Table 4 - Chemical data for river from Karnali basin and Siwaliks.

\begin{tabular}{|c|c|c|c|c|c|c|c|c|}
\hline Sample & River & Location & Date & Unit & Altitude & $\begin{array}{l}\mathrm{TDS} \\
\mathrm{mg} / \mathrm{l}\end{array}$ & $\begin{array}{l}\mathrm{Sr}^{2+} \\
\mu \mathrm{mol}\end{array}$ & ${ }^{87} \mathrm{Sr} /{ }^{86} \mathrm{Sr}$ \\
\hline$\overline{\mathrm{NH}} 80$ & Thuli Bheri & Dunai & 21.mar.95 & & 2030 & 234 & 2.75 & 0.7226 \\
\hline NAG 47 & Thuli Bheri & Dunai & 25. nov.95 & & 2030 & 229 & 2.59 & 0.7216 \\
\hline $94-12$ & & Sarmi & 16.mar.94 & $\mathrm{LH}$ & 1630 & 249 & 0.20 & 0.7777 \\
\hline 94-11 & Jagdula & Luhu & 15.mar.94 & & 1580 & 184 & 1.66 & 0.7266 \\
\hline $94-10$ & Thuli Bheri & Laha & 15.mar.94 & & 1600 & 225 & 2.21 & 0.7288 \\
\hline $94-09$ & Bheri & Tallu & 14.mar.94 & & 1280 & 217 & 2.15 & 0.7292 \\
\hline $94-08$ & Bheri & Radijiula & 12.mar.94 & & 1010 & 216 & 1.58 & 0.7380 \\
\hline 94-07 & Bheri & Ramnaghat & 11.mar.94 & & 830 & 217 & 1.26 & 0.7516 \\
\hline $94-06$ & Joug & Sahare & 10.mar.94 & & & 207 & 0.71 & 0.7328 \\
\hline NAG 14 & Bheri & Sampujighat & 18.nov.95 & & 370 & 195 & 1.15 & 0.7446 \\
\hline $94-16$ & Bheri & Ghatgaun & 27.mar.94 & & & 222 & 1.23 & 0.7647 \\
\hline $94-15$ & Karnali & Ghatgaun & 25.mar.94 & & & 161 & 1.23 & 0.7286 \\
\hline NAG 11 & Karnali & Kotillaghat & 17.nov.95 & & 100 & 229 & 1.30 & 0.7299 \\
\hline NAG 19 & Rapti & Darbang & 21.nov.95 & & 290 & 229 & 1.34 & 0.7351 \\
\hline NAG 10 & Rapti & Bhabaniyapur & 16.nov.95 & & 140 & 274 & 1.37 & 0.7327 \\
\hline $94-05$ & Sarda & Luham & 8.mar.94 & & 1400 & 200 & 0.51 & 0.7317 \\
\hline NAG 15 & Sarda & Luham & 16.nov.95 & & 1400 & 140 & 0.78 & 0.7273 \\
\hline \multicolumn{9}{|c|}{ SIWALIKS } \\
\hline $94-01$ & Chor & Upper part & 2.mar.94 & & & 670 & 4.02 & 0.7250 \\
\hline $94-02$ & Surâ̂ & Upper part & 4.mar.94 & & & 599 & 4.32 & 0.7354 \\
\hline $94-03$ & Rangsing & Charange & 5.mar.94 & & & 331 & 1.77 & 0.7304 \\
\hline $94-13$ & Gadel & Palaite & 23.mar.94 & & & 325 & 0.74 & 0.7234 \\
\hline $94-14$ & Basunti & Bashanti & 24.mar.94 & & & 270 & 0.49 & 0.7278 \\
\hline $94-17$ & Kachali & & 29.mar.94 & & & 403 & 4.28 & 0.7195 \\
\hline $94-18$ & Banka & & 29.mar.94 & & & 477 & 4.91 & 0.7201 \\
\hline
\end{tabular}


Table 5 - Chemical data for rivers in Bangladesh

\begin{tabular}{|c|c|c|c|c|c|c|}
\hline Sample & River & Location & Date & $\begin{array}{l}\text { TDS } \\
\mathrm{mg} / \mathrm{l}\end{array}$ & $\begin{array}{c}\mathrm{Sr}^{2+} \\
\mu \mathrm{mol} /\end{array}$ & ${ }^{87} \mathrm{Sr} /{ }^{86} \mathrm{Sr}$ \\
\hline BGP 12 & Tista & Kaunia & 4.aug.96 & $\overline{41}$ & 0.17 & 0.7698 \\
\hline BGP 72 & Tista & Kaunia & 7.mar.97 & 79 & 0.33 & 0.7683 \\
\hline BGP 4 & Ganges & Rajshahi & 2.aug.96 & 125 & 0.56 & 0.7291 \\
\hline BGP 65 & Ganges & Rajshahi & 3.mar.97 & 374 & 2.71 & 0.7235 \\
\hline BGP 15 & Brahmaputra & Chilmari & 5.aug.96 & 105 & 0.32 & 0.7413 \\
\hline BGP 79 & Brahmaputra & Chilmari & 7.mar.97 & 145 & 0.90 & 0.7218 \\
\hline BGP 51 & Brahmaputra & Aricha Ghat & 25.feb.97 & 154 & 0.99 & 0.7260 \\
\hline BGP 39 & Upper Meghna & Bhairab Bazar & 13.aug.96 & 38 & 0.22 & 0.7160 \\
\hline BGP 0 & Upper Meghna & Nangalband & 20.oct.94 & 47 & 0.23 & 0.7162 \\
\hline BGP 20 & Lower Meghna & Bhola & 10.aug.96 & 127 & 0.70 & 0.7226 \\
\hline
\end{tabular}

Table 6 - Average chemical composition of river water in the G-B system

\begin{tabular}{c|ccccccc}
\hline Zone & LO 47 & \multicolumn{7}{c}{ North Flank } & Mustang & South Flank South Flank & Ganges & Brahmaputra \\
Type & Spring & Composite & Graben & Composite & Gneiss & & \\
$\mathrm{n}$ & & 6 & 11 & 26 & 11 & & \\
$\mathrm{TDS}$ & 8590 & 240 & 410 & 140 & 30 & 130 & 110 \\
$\mathrm{HCO}_{3}{ }^{-}$ & 36420 & 2060 & 2900 & 1540 & 310 & 1420 & 1110 \\
$\mathrm{Cl}^{-}$ & 93090 & 20 & 710 & 40 & 10 & 90 & 20 \\
$\mathrm{SO}_{4}^{2-}$ & 130 & 790 & 1080 & 110 & 30 & 80 & 60 \\
$\mathrm{Na}^{+}$ & 111050 & 90 & 1140 & 130 & 70 & 180 & 100 \\
$\mathrm{~K}^{+}$ & 7580 & 30 & 110 & 40 & 20 & 70 & 50 \\
$\mathrm{Mg}^{2+}$ & 3660 & 550 & 820 & 270 & 20 & 200 & 170 \\
$\mathrm{Ca}^{2+}$ & 2080 & 1220 & 1420 & 550 & 120 & 470 & 390 \\
$\mathrm{H}_{2} \mathrm{SiO}_{4}$ & & 80 & 130 & 100 & 120 & 130 & 160 \\
$\mathrm{Sr}^{2+}$ & 167.2 & 3.4 & 5.8 & 0.69 & 0.12 & & \\
$87 \mathrm{Sr}^{2} 86 \mathrm{Sr}$ & 0.7306 & 0.718 & 0.717 & 0.749 & 0.741 & & \\
\hline $\mathrm{All}^{2}$ & & & &
\end{tabular}

All data are rounded average and therefore may not satisfy the charge neutrality. TDS are in $\mathrm{mg} / \mathrm{l}$ and all other species are in $\mu \mathrm{mol} / \mathrm{l}$. 
Table 7 - Sr composition of rainwaters

\begin{tabular}{|c|c|c|c|c|c|}
\hline Sample & Date & $\begin{array}{l}\text { TDS } \\
\mathrm{mg} / 1\end{array}$ & $\begin{array}{c}\mathrm{Sr} \\
\mathrm{nmol} / 1\end{array}$ & $87 \mathrm{Sr} / 86 \mathrm{Sr}$ & \pm \\
\hline \multicolumn{6}{|c|}{ KATHMANDU } \\
\hline Orage & 29.may.93 & 9.4 & 47.3 & 0.71229 & 0.00009 \\
\hline NAG 50 & 22.jul.95 & 25.5 & 600 & 0.71607 & 0.00001 \\
\hline NAG 51 & 07.aug.95 & 18.3 & 404 & 0.71467 & 0.00002 \\
\hline NAG 52 & 19.aug.95 & 4.5 & 50.9 & 0.71452 & 0.00010 \\
\hline NAG 53 & 22. sep.95 & 31.2 & 91.3 & 0.71449 & 0.00009 \\
\hline NAG 54 & 29.sep.95 & 10.4 & 32.8 & 0.71359 & 0.00013 \\
\hline NAG 1 & 10.nov.95 & 6.4 & 32.1 & 0.70983 & 0.00010 \\
\hline GK2 & 20.may.96 & 26.6 & 127 & 0.72505 & 0.00007 \\
\hline GK5 & 07.jul.96 & 7.6 & 15.3 & 0.71304 & 0.00024 \\
\hline GK6 & 03.aug.96 & 20.4 & 50.5 & 0.71495 & 0.00058 \\
\hline GK8 & 09.sep.96 & 176 & 679 & 0.71180 & 0.00011 \\
\hline KTM 1 & 25.jun-09.jul & 0.8 & 5.8 & nd & \\
\hline KTM 2 & 10.jul-24.jul & 2.5 & 23.0 & nd & \\
\hline KTM 3 & 25.jul-05.aug & 2.0 & 12.8 & nd & \\
\hline КТМ 4 & 06.aug-24.aug & 1.9 & 12.1 & nd & \\
\hline KTM 5 & 25.aug-07.sep & 4.1 & 32.3 & nd & \\
\hline КТM 6 & 08.sep-29.sep & 4.9 & 32.5 & nd & \\
\hline \multicolumn{6}{|l|}{ NEPAL } \\
\hline $\mathrm{NAG} 2^{\| 1}$ & 10.nov.95 & 2.0 & 7.10 & 0.71303 & 0.00019 \\
\hline MO 17B & & 5.0 & 12.8 & nd & \\
\hline MO 46 & & 2.6 & 16.1 & nd & \\
\hline MO & & 1.9 & 5.11 & nd & \\
\hline MO 76 & & 1.7 & 3.52 & nd & \\
\hline \multicolumn{6}{|c|}{ BANGLADESH } \\
\hline BGP1 & 29.jul.96 & 15.3 & 59.2 & 0.71182 & 0.00009 \\
\hline BGP2 & 31.jul.96 & 2.6 & 10.9 & 0.70957 & 0.00032 \\
\hline BGP2 ${ }^{\#}$ & 31.jul.96 & 2.6 & 12.2 & 0.70966 & 0.00014 \\
\hline BGP9 & 03.aug.96 & 2.2 & 5.83 & 0.71184 & 0.00024 \\
\hline BGP10 & 04.aug.96 & 0.7 & 4.81 & 0.71217 & 0.00018 \\
\hline BGP17 & 07.aug.96 & 0.8 & 6.94 & 0.71912 & 0.00074 \\
\hline BGP 35 & 13.aug.96 & 11.7 & 58.0 & 0.71101 & 0.00009 \\
\hline
\end{tabular}

II : Sample from Pokkara. The MO sample are from unoccupied area. \# : Duplicate. 
Table 8 - Isotopic chemistry of Carbonate from Nepal bedrock

\begin{tabular}{|c|c|c|c|c|c|c|c|c|c|c|}
\hline & Sample & & Lithology & $\begin{array}{l}\mathrm{Ct} \\
\%\end{array}$ & $\begin{array}{c}\text { Dol } \\
\%\end{array}$ & $\begin{array}{c}\delta^{13} \mathrm{C} \\
\% o\end{array}$ & $\begin{array}{c}\delta^{18} \mathrm{O} \\
\% o\end{array}$ & $\begin{array}{c}\mathrm{Rb} \\
\mathrm{ppm}\end{array}$ & $\begin{array}{c}\mathrm{Sr} \\
\mathrm{ppm}\end{array}$ & ${ }^{87} \mathrm{Sr} /{ }^{86} \mathrm{Sr}$ \\
\hline TSS & $\begin{array}{l}\text { NL 178 } \\
\text { DK } 30^{\#} \\
\text { DK 29 } 29^{\#} \\
\text { NL 449 } \\
\text { T } 22 \\
\text { T } 24 \\
\text { T } 205\end{array}$ & $\begin{array}{l}\text { Mesozoic } \\
\text { Palaeozoic } \\
\text { Palaeozoic } \\
\text { Palaeozoic } \\
\text { Palaeozoic } \\
\text { Palaeozoic } \\
\text { Palaeozoic }\end{array}$ & $\begin{array}{c}\text { Limestone } \\
\text { Calc-schist } \\
\text { Calc-schist } \\
\text { Limestone } \\
\text { Marble } \\
\text { Marble } \\
\text { Marble }\end{array}$ & 62.0 & 10.9 & $\begin{array}{l}-2.5 \\
-2.1 \\
-2.5\end{array}$ & $\begin{array}{l}13.8 \\
15.1 \\
16.4\end{array}$ & $\begin{array}{c}49.5 \\
62 \\
50.5 \\
46\end{array}$ & $\begin{array}{l}1600^{\S} \\
759^{\S} \\
868^{\S} \\
773^{\S} \\
253 \\
543 \\
909\end{array}$ & $\begin{array}{c}0.7079 \\
0.7109 \\
0.7110 \\
0.7119 \\
0.71494 \\
0.71279 \\
0.71365\end{array}$ \\
\hline HHC & $\mid \begin{array}{l}\text { NL } 6233^{\#} \\
\text { T } 255 \\
\text { F II }\end{array}$ & $\begin{array}{l}\text { F II } \\
\text { F II } \\
\text { F II }\end{array}$ & $\begin{array}{c}\text { Marble } \\
\text { Pyr Marble } \\
\text { Gneiss }\end{array}$ & 0.76 & 0.02 & $\begin{array}{l}-3.0 \\
-5.8\end{array}$ & $\begin{array}{l}14.6 \\
8.3^{\mathbb{I}}\end{array}$ & 5 & $\begin{array}{l}773^{\S} \\
832 \\
101\end{array}$ & $\begin{array}{c}0.7141 \\
0.71523 \\
0.71777\end{array}$ \\
\hline LHN & $\begin{array}{l}\text { AP 74-207 } \\
\text { AP 75-811 } \\
\text { AP 75-865 } \\
\text { AP 75-867 } \\
\text { DA } 15\end{array}$ & & $\begin{array}{l}\text { Dolostone } \\
\text { Dolostone } \\
\text { Dolostone } \\
\text { Dolostone } \\
\text { Limestone }\end{array}$ & $\begin{array}{l}12.7 \\
31.5 \\
12.5 \\
17.0 \\
68.9 \\
\end{array}$ & $\begin{array}{l}47.0 \\
31.0 \\
58.0 \\
65.0 \\
1.49 \\
\end{array}$ & $\begin{array}{l}-1.7 \\
-3.1 \\
-1.3 \\
-0.9 \\
-3.4 \\
\end{array}$ & $\begin{array}{l}14.8 \\
15.2 \\
21.7 \\
21.1 \\
19.1^{\text {đI }}\end{array}$ & & $\begin{array}{l}53.3 \\
54.8 \\
41.0 \\
28.0 \\
76.4\end{array}$ & $\begin{array}{l}0.85722 \\
0.74639 \\
0.75872 \\
0.73950 \\
0.71747\end{array}$ \\
\hline
\end{tabular}

$\S$ : Whole rock digestion, all the others are leachates. \# : Data from Deniel (1985). $\delta^{18} \mathrm{O}$ of whole carbonates are from France-Lanord, 1987; France-Lanord et al., 1988 and those labelled II are this study.

Table 9 - Isotopic chemistry of Carbonate from bedload sediment

\begin{tabular}{lccccccccc}
\hline Sample & $\begin{array}{c}\text { Corresponding } \\
\text { Water Sample }\end{array}$ & $\begin{array}{c}\mathrm{Ct} \\
\%\end{array}$ & $\begin{array}{c}\text { Dol } \\
\%\end{array}$ & $\begin{array}{c}\delta^{13} \mathrm{Co} \\
\%\end{array}$ & $\begin{array}{c}\delta^{18} \mathrm{O} \\
\text { KaLI GANDAKI }\end{array}$ & $\begin{array}{c}\mathrm{Sr} \\
\mathrm{ppm}\end{array}$ & $\begin{array}{c}\mathrm{Rb} \\
\mathrm{ppm}\end{array}$ & ${ }^{87 \mathrm{Rb} /{ }^{86} \mathrm{Sr} r}$ & ${ }^{87} \mathrm{Sr} / 86 \mathrm{Sr}$ \\
\hline LO 50 & LO 49 & 5.64 & 0.71 & 1.04 & 14.9 & 485 & 2.2 & 0.013 & 0.71437 \\
LO 64 & LO 63 & 1.59 & 0.72 & -0.40 & 17.1 & 395 & 2.7 & 0.020 & 0.71445 \\
LO2 & LO 1 & 31.1 & 2.26 & 1.76 & 15.4 & 608 & & & 0.71082 \\
NAG 20 & NAG 21 & 32.3 & 2.14 & 1.59 & 17.0 & 580 & 2.0 & 0.010 & 0.70955 \\
NAG 25 & NAG 21 & 28.0 & 1.57 & 1.92 & 15.7 & 499 & 4.9 & 0.028 & 0.71124 \\
NAG 33 & NAG 34 & 29.1 & 3.67 & 0.90 & 17.2 & 702 & nd & - & 0.71119 \\
NAG 36 & NAG 34 & 30.8 & 3.11 & 0.94 & 17.0 & 646 & 1.0 & 0.004 & 0.71086 \\
NAG 38 & NAG 39 & 27.5 & 2.57 & 0.58 & 17.1 & 691 & nd & - & 0.71153 \\
NAG 42 & NAG 43 & 27.8 & 2.49 & 0.04 & 17.0 & 662 & nd & - & 0.71262 \\
NAG 44 & NAG 45 & 14.1 & 2.55 & -0.49 & 16.9 & 678 & 0.8 & 0.003 & 0.71506 \\
LO 311 & LO 310 & 13.0 & 4.54 & -1.18 & 17.9 & 475 & 3.0 & 0.018 & 0.72388 \\
NAG 6 & NAG 5 & 14.4 & 5.12 & -0.81 & 17.5 & 438 & 1.7 & 0.011 & 0.72101 \\
LO 307 & LO 306 & 8.49 & 3.80 & -1.18 & 18.3 & 524 & 0.9 & 0.005 & 0.72307 \\
TRISULI & & & & & & & & & \\
KN 83 & KN 84 & 0.05 & 0.011 & -0.8 & 18.7 & 402 & nd & - & 0.73044 \\
KN 101 & KN 102 & 0.002 & 0.021 & -4.3 & 12.8 & 238 & nd & - & 0.74165 \\
LO259 & LO 258 & 12.4 & 0.69 & 1.12 & 20.2 & 583 & 1.6 & 0.008 & 0.71170 \\
TRI 6/7 & TRI 6/7 & 0.14 & 0.24 & -0.76 & 18.2 & 222 & nd & - & 0.73653 \\
TRI 15/9 & TRI 15/9 & 0.60 & 0.32 & -0.45 & 17.5 & 579 & 1.2 & 0.006 & 0.72230 \\
TRI 1/12 & TRI 1/12 & 0.11 & 0.23 & -0.53 & 17.6 & 242 & nd & - & 0.73641 \\
TRI 4/4 & TRI 4/4 & 0.66 & 0.30 & -0.47 & 17.6 & 453 & nd & - & 0.72409 \\
LO 317 & LO 316 & 0.20 & 0.14 & -1.05 & 22.1 & 252 & 8.3 & 0.093 & 0.73760 \\
NAYARANI & & & & & & & & & \\
NAG 48 & NAG 49 & 9.82 & 3.96 & -0.83 & 17.7 & 533 & 0.9 & 0.005 & 0.71902
\end{tabular}


Table 10 - Isotopic chemistry of Carbonate from bed load sediment

\begin{tabular}{|c|c|c|c|c|c|c|c|c|c|}
\hline \multirow[t]{2}{*}{ Sample } & Corresponding & $\mathrm{Ct}$ & Dol & $\delta^{13} \mathrm{C}$ & $\delta^{18} \mathrm{O}$ & $\mathrm{Sr}$ & $\mathrm{Rb}$ & \multirow[t]{2}{*}{${ }^{87} \mathrm{Rb} / 86 \mathrm{Sr}$} & \multirow[t]{2}{*}{${ }^{87} \mathrm{Sr} / 86 \mathrm{Sr}$} \\
\hline & Water Sample & $\%$ & & $\%$ & $\%$ & ppm & ppm & & \\
\hline \multicolumn{10}{|l|}{ SETI } \\
\hline NAG 4 & NAG 3 & 0.30 & 0.36 & -2.32 & 19.8 & 122 & 4.4 & 0.103 & 0.75490 \\
\hline NAG $4 *$ & NAG 3 & 0.18 & 0.26 & -2.32 & 17.5 & 119 & 3.7 & 0.088 & 0.73364 \\
\hline HF 10 & & 53.3 & 3.44 & -0.82 & 18.7 & nd & nd & 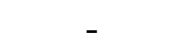 & 0.71349 \\
\hline HF 11 & & 41.3 & 4.62 & -0.68 & 18.6 & nd & nd & - & 0.71307 \\
\hline \multicolumn{10}{|c|}{ MARSYANDI } \\
\hline NAG 22 & NAG 24 & 20.1 & 4.60 & 0.69 & 10.2 & 188 & 0.9 & 0.013 & 0.71162 \\
\hline LO 315 & LO 314 & 34.0 & 3.07 & -0.51 & 17.6 & 641 & & & 0.71306 \\
\hline \multicolumn{10}{|c|}{ BHURI GANDAKI } \\
\hline LO 301 & LO 300 & 2.38 & 1.26 & -0.57 & 17.2 & 354 & 2.0 & 0.016 & 0.72467 \\
\hline \multicolumn{10}{|c|}{ BHERI-KARNALI } \\
\hline R 94-12 & R 94-12 & 3.23 & 65.5 & -0.51 & 20.5 & 63.8 & 0.2 & 0.008 & 0.76382 \\
\hline NAG 13 & NAG 14 & 7.13 & 4.93 & -0.60 & 18.7 & 372 & & & 0.72803 \\
\hline NAG 12 & NAG 11 & 4.04 & 4.30 & -1.06 & 19.7 & 345 & & & 0.72348 \\
\hline \multicolumn{10}{|l|}{ GANGES } \\
\hline BGP 5 & BGP 4 & 4.59 & 2.52 & -1.13 & 20.2 & 478 & 0.6 & 0.003 & 0.71832 \\
\hline BGP 6 & BGP 4 & 3.03 & 1.51 & -0.99 & 18.7 & 436 & 0.8 & 0.005 & 0.71978 \\
\hline BGP 7\# & BGP 4 & 4.04 & 2.03 & -1.27 & 21.5 & nd & nd & nd & nd \\
\hline BGP 68 & BGP 65 & 2.38 & 1.35 & -0.98 & 19.2 & 391 & 1.2 & 0.009 & 0.72059 \\
\hline \multicolumn{10}{|c|}{ BRAHMAPUTRA } \\
\hline BGP 14 & BGP 15 & 0.024 & 0.53 & 0.88 & 18.6 & 164 & 1.6 & 0.028 & 0.74855 \\
\hline BGP 18\# & BGP 15 & 0.15 & 1.07 & 1.20 & 20.2 & nd & nd & nd & nd \\
\hline BGP 82 & BGP 79 & 0.003 & 0.004 & -4.13 & 23.1 & 470 & 6.7 & 0.040 & 0.72665 \\
\hline
\end{tabular}

Table 11 - Mean Sr composition of TSS, HHC and LH rivers and water discharge infered from $\mathrm{Sr}$ mass balance and hydrology

\begin{tabular}{ccccc}
\hline & Period & TSS & HHC & LH \\
{$[\mathrm{Sr}] \mu \mathrm{mol} / \mathrm{l}$} & & $6.13 \pm 0.62$ & $0.23 \pm 0.09$ & $0.38 \pm 0.20$ \\
${ }^{87} \mathrm{Sr} / 86 \mathrm{Sr}$ & & $0.717 \pm 0.001$ & $0.739 \pm 0.002$ & $0.783 \pm 0.006$ \\
\hline Kali & June & $10 \%$ & $5 \%$ & $85 \%$ \\
Kali & Nov & $10 \%$ & $5 \%$ & $85 \%$ \\
Kali \# & Year & $11 \%$ & $5 \%$ & $84 \%$ \\
Trisuli & June & $10 \%$ & $80 \%$ & $10 \%$ \\
Trisuli & Nov & $5 \%$ & $65 \%$ & $30 \%$ \\
Trisuli \# & Year & $14 \%$ & $63 \%$ & $24 \%$ \\
Narayani & June & $10 \%$ & $20 \%$ & $70 \%$ \\
Narayani & Nov & $15 \%$ & $0 \%$ & $85 \%$ \\
Narayani \# & Year & $11 \%$ & $28 \%$ & $61 \%$ \\
\hline
\end{tabular}

\# : Hydrological data after Hurtrez (1998). The mean isotopic 